\title{
Toward a Fundamental Understanding of the Role of Lignin in the Biorefinery Process
}

OPEN ACCESS

Edited by:

Uwe Schröder,

University of Greifswald, Germany

Reviewed by:

Maobing Tu,

University of Cincinnati, United States Junhua Zhang,

Northwest A\&F University, China

${ }^{*}$ Correspondence:

Arthur J. Ragauskas

aragausk@utk.edu

Specialty section:

This article was submitted to

Bioenergy and Biofuels,

a section of the journal

Frontiers in Energy Research

Received: 28 October 2021

Accepted: 01 December 2021

Published: 03 January 2022

Citation:

Yao L, Yang $H$, Meng $X$ and

Ragauskas AJ (2022) Toward a

Fundamental Understanding of the

Role of Lignin in the

Biorefinery Process.

Front. Energy Res. 9:804086.

doi: 10.3389/fenrg.2021.804086

\begin{abstract}
Lan Yao ${ }^{1,2}$, Haitao Yang ${ }^{2}$, Xianzhi Meng ${ }^{3}$ and Arthur J. Ragauskas ${ }^{3,4,5 *}$
${ }^{1}$ Key Laboratory of Fermentation Engineering (Ministry of Education), College of Bioengineering, Hubei University of Technology, Wuhan, China, ${ }^{2}$ Hubei Provincial Key Laboratory of Green Materials for Light Industry, Hubei University of Technology, Wuhan, China, ${ }^{3}$ Department of Chemical and Biomolecular Engineering, University of Tennessee Knoxville, Knoxville, TN, United States, ${ }^{4}$ Biosciences Division, Oak Ridge National Laboratory (ORNL), Joint Institute for Biological Sciences, Oak Ridge, TN, United States, ${ }^{5}$ Department of Forestry, Wildlife, and Fisheries, Center for Renewable Carbon, Institute of Agriculture, The University of Tennessee Knoxville, Knoxville, TN, United States
\end{abstract}

As one of the main components in biomass, lignin plays a vital role in the biorefinery industry. Its unique structural feature increases the dose of cellulases during enzymatic deconstruction and is an attractive resource for many high valued products. The inhibition of lignin on cellulases is proposed to occur in several ways, with the most studied being nonproductive enzyme binding, which is attributed to hydrogen bonding, hydrophobic and/or electrostatic interactions. This review provides a comprehensive review of how lignin is transformed during various pretreatment methods as well as how these changes impact the cellulases inhibition. Future pretreatment directions for decreased cellulases inhibition are also proposed.

Keywords: lignin, biorefinery, cellulase adsorption, valorization, pretreatment

\section{INTRODUCTION}

Due to the depletion of fossil fuels, environmental and energy security concerns, alternative renewable energy from biomass has attracted intensive attention worldwide (Ragauskas et al., 2014; Cole-Hamilton, 2020). Cellulose, hemicellulose, and lignin are the three main components in biomass (Wörmeyer et al., 2011). Cellulose and hemicellulose can be hydrolyzed to glucose or xylose which can be subsequently fermented by yeast or bacteria to yield various types of liquid fuel (e.g., ethanol and butanol). Lignin, a polymer comprised of cross-linked phenylpropane units, contributes to several biomass features, including hydrophobicity, structural rigidity, and microbial resistance to plant cell walls (Saini et al., 2016). Typically, biofuels production from lignocellulosics mainly consists of three key steps: namely biomass pretreatment, enzymatic hydrolysis/saccharification, and fermentation.

However, it has been found that lignin adversely impacts enzymatic hydrolysis, resulting in an increased dose of cellulases, which accounts for almost half of bioethanol cost (Luterbacher et al., 2014). It was suggested that ideal pretreatments should maximize lignin removal and minimize polysaccharide modification (Ding et al., 2012). Therefore, how to decrease the inhibitory effect of lignin on cellulases becomes one of the major challenges in biofuels production for assorted bioresources. To mitigate the adverse effects of lignin and fundamentally decrease the overall cost of biofuel, how lignin impacts cellulases performance during enzymatic hydrolysis needs to be understood and has been extensively explored. 
TABLE 1 | Typical biomass constituents for select plant resources (Ragauskas et al., 2014).

\begin{tabular}{lccc}
\hline Plant resource & Cellulose $\%$ & Hemicellulose $\%$ & Lignin $\%$ \\
\hline Miscanthus & $45-52$ & $24-33$ & $9-13$ \\
Switchgrass & $37-42$ & $26-33$ & $17-18$ \\
Corn stover & 37 & 31 & 18 \\
Poplar & $42-48$ & $16-22$ & $21-27$ \\
Eucalyptus & $39-46$ & $24-28$ & $29-32$ \\
Pine & 46 & 23 & 28
\end{tabular}

\subsection{Structural Features of Lignin}

Lignin is a heterogeneous macromolecular polymer composed of guaiacyl $(\mathrm{G})$, syringyl $(\mathrm{S})$, and/or $p$-hydroxyphenyl $(\mathrm{H})$, which are connected by carbon-carbon and aryl ether interunit linkages. Depending on the plant species, the contents of lignin and its G, S, and $\mathrm{H}$ units vary significantly. As shown in Table 1, softwoods, such as pine, contain $\sim 28 \%$ lignin, which mainly consists of G units. Lignin from hardwoods (i.e., poplar and eucalyptus) comprises both of $\mathrm{G}$ and $\mathrm{S}$ units and accounts for $21-32 \%$ of the plant cell wall. Besides $G$ and $S$ units, lignin from herbaceous species (i.e., miscanthus, switchgrass, and corn stover) also contains small amounts of $\mathrm{H}$ units. This latter bioresource contains the least amount of lignin, typically less than $20 \%$.

The common interunit linkages in lignin include $\beta-O-4, \beta-5$, $\beta-\beta^{\prime}, \beta-1$, and $5-5^{\prime} / 4-O-\beta^{\prime}$, as depicted in Figure 1. As shown by earlier researchers, the $\beta-\mathrm{O}-4$ linkage is the dominant interunit linkage in lignin and its presence in "natural levels" indicates the intactness of native lignin. The remaining key interunit linkages include phenylcoumaran $(\beta-5)$, resinols $\left(\beta-\beta^{\prime}\right)$, and dibenzodioxocin $\left(5-5^{\prime} / 4-\mathrm{O}-\beta^{\prime}\right)$ and spirodienone $(\beta-1)$.

\subsection{Cellulases-Lignin Interactions During Enzymatic Hydrolysis Process}

The interaction between lignin and cellulases is very complicated. The most focused research area is lignin-derived inhibition, which has been proposed to occur in three ways: (I) physical barrier, (II) nonproductive binding, and (III) deactivation of enzymes by lignin fragments of small molecular weight, as shown in Figure 2.

\subsubsection{Lignin's Physical Barrier Properties}

Lignin can block the access of enzymes to cellulose as a physical barrier, which is one of the main reasons for the low glucose yield from the enzymatic hydrolysis of native biomass. Earlier studies supported the hypothesis that lignin extraction and deposition during hydrothermal pretreatment might decreased the enzymatic hydrolysis rate over time (Selig et al., 2007; Donohoe et al., 2008; Hansen et al., 2011). In a series of studies, Lai et al. demonstrated that these solvent extractable lignin droplets from ethanol organosolv pretreatment could also have positive effect on enzymatic hydrolysis (Lai et al., 2018b). A micro-spectroscopic approach combining stimulated Raman scattering microscopy and fluorescence lifetime imaging microscopy was employed to understand the roles lignin play in biomass recalcitrance after maleic acid pretreatment (Zeng et al., 2015). Results showed that both dense lignin droplets and loosely packed lignin droplets were formed (Figure 3). Li and his coworkers found that lignin droplets relocated onto the Avicel surface after hydrothermal pretreatment of a mixture of Avicel cellulose and poplar wood as a lignin source, significantly inhibited cellulose hydrolysis (Li et al., 2014). Similarly, researchers also found that after liquid hot water pretreatment, spherical droplets appeared on the surface and in the corners of the disrupted cell walls, which might act as a physical barrier inhibiting the access of enzymes to the inner region of cell walls (Donohoe et al., 2008; Ko et al., 2015b; Wang et al., 2015b). The removal of droplets by 1, 4-dioxane extraction was shown to increase the glucose yield from cellulases treatment from 16.3 to 23.0\% (He et al., 2020a). Recently, THF-water co-solvent system with dilute sulfuric acid was applied to solubilize redeposited lignin and overcome the limitations of traditional dilute sulfuric acid pretreatment. It was suggested that this co-solvent could

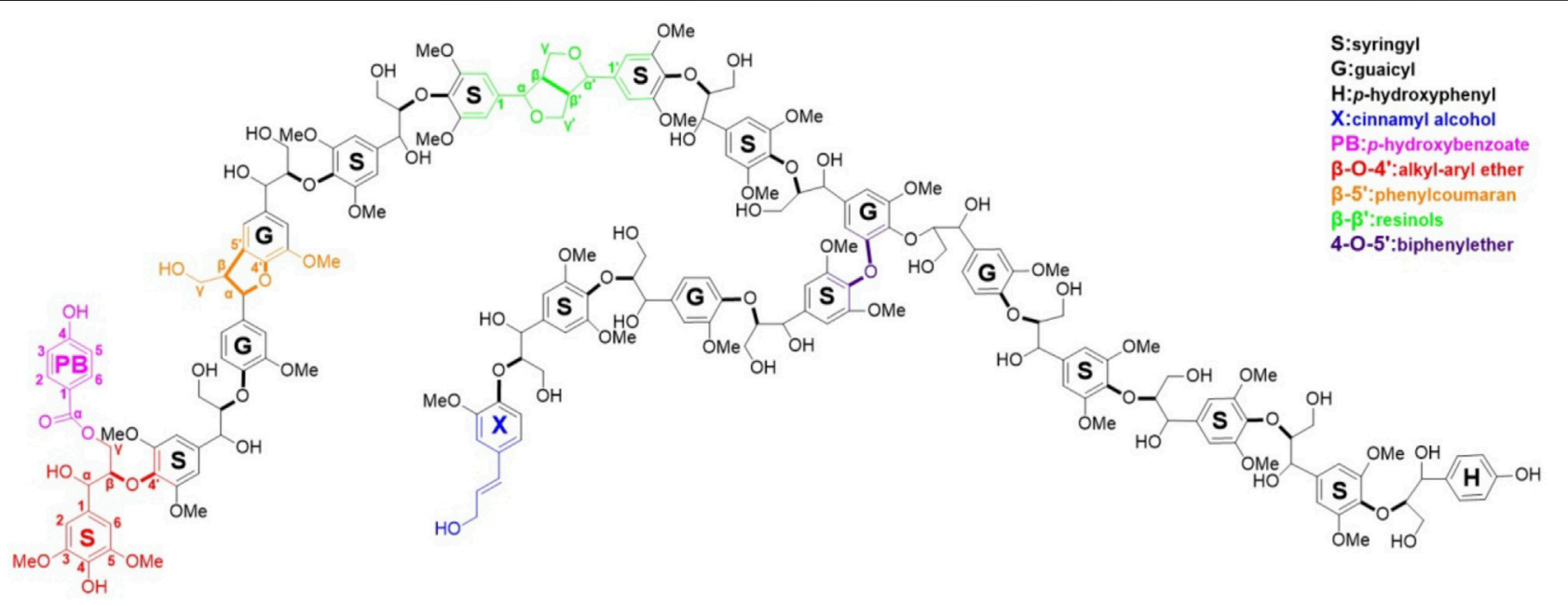

FIGURE 1 | Typical hardwood lignin structure (Li M. et al., 2016). 


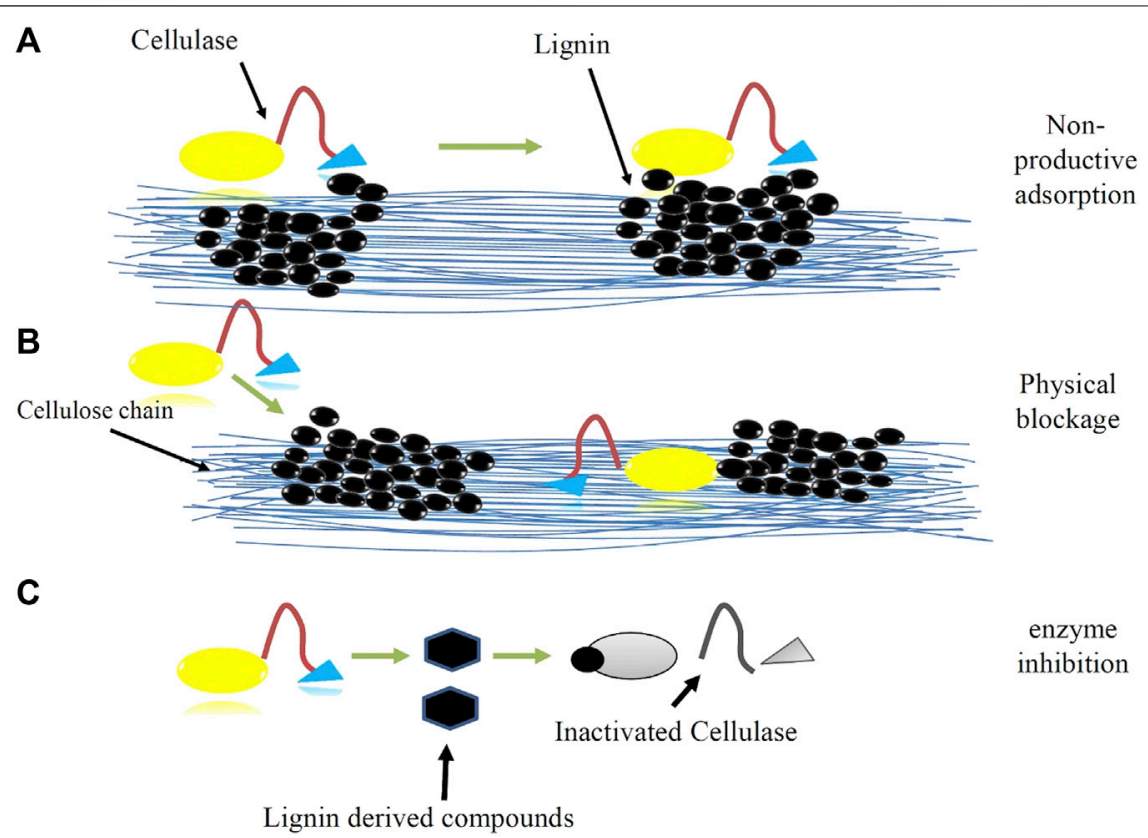

FIGURE 2 | Inhibition of cellulases by lignin. (A) Nonproductive adsorption of cellulases onto lignin, (B) Physical blockage of cellulases progress on lignocellulose chain, (C) enzyme inhibition due to soluble lignin-derived compounds cellulases (Saini et al., 2016).

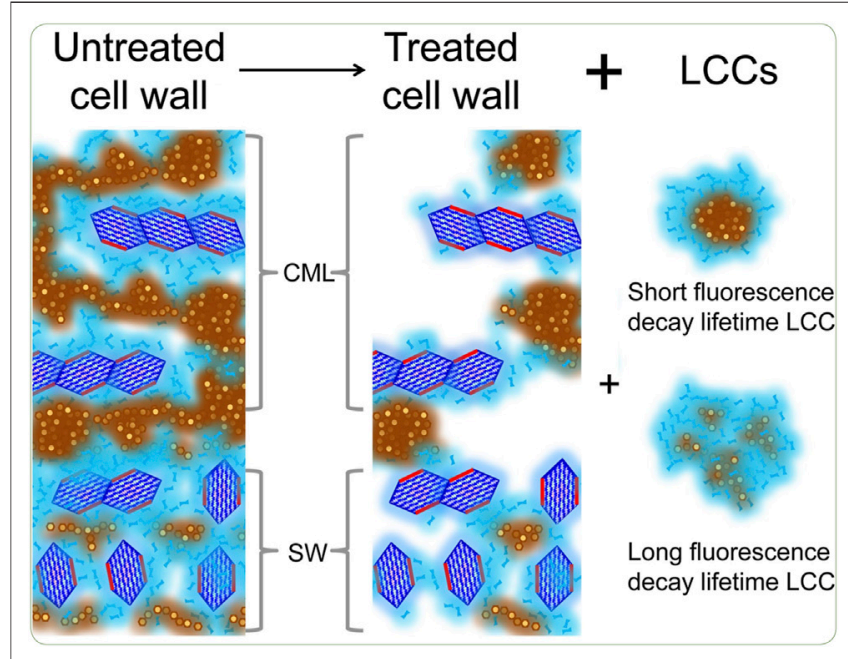

FIGURE 3 | Formation of dense lignin droplets and loosely packed lignin droplets during maleic acid pretreatment (Zeng et al., 2015).

prevent lignin redeposition onto the biomass surface and prolong cellulases activity (Patri et al., 2021).

Microscopic analysis showed that after autohydrolysis pretreatment, lignin from Eucalyptus globulus migrates out of the cell wall and redeposits in certain regions of the fibers to form droplet-like structures. The authors reported that the regions of the cell wall adjacent to the coalesced lignin appear to open and improved the accessibility of cellulose to enzymes (Araya et al., 2015). Another study using a lime pretreatment showed that tiny droplets were formed on the sweet sorghum bagasse surface, which could increase cellulose conversion rate and at the same time reduce carbohydrates loss by forming a complex with lignin and calcium ions (Yan et al., 2015). The inconsistency of the obtained results indicated that the fundamentals behind the impact of lignin droplets on cellulose accessibility are still not fully understood, and more studies are needed to clarify the mechanisms.

\subsubsection{Nonproductive Binding of Lignin to Cellulases}

The nonproductive binding of cellulases to lignin has attracted much attention recently. This binding effect has been attributed to hydrophobic interactions, electrostatic forces, and/or hydrogen bonding. Hydrophobic interactions were reported to be the dominant driving force in cellulases binding to lignin, which was revealed by atomic force microscopy between specialized tips with hydrophobic, $-\mathrm{OH}$, and $-\mathrm{COOH}$ groups, and immobilized cellulases (Qin et al., 2014). Lignin is more hydrophobic than any other major component in biomass (Hodgson and Berg, 1988). It was found that proteins could be adsorbed at the hydrophobic surfaces of lignin (Saini et al., 2016). A study on cellulases adsorption to different lignin preparations correlated carboxylic acid groups in lignin and cellulases adsorption. They suggested that the carboxylic acid content could impact the hydrophilicity of the lignin, which in turn affects the nonproductive binding of the cellulases to lignin (Pareek et al., 2013). By investigating the association of aspen lignins after hydrothermal pretreatment at various pretreatment severities with cellulases binding, Sun and his coworkers found that the condensed aromatic rings enhanced the hydrophobic interactions between lignin and cellulases, which are mainly responsible for 
the inhibitory effect of lignin on cellulases (Sun et al., 2016). Other studies also obtained similar results (Yu et al., 2014; Ko et al., 2015a; Yao et al., 2018a).

Previous studies found that hydrogen bonding was another major driving force for cellulases adsorption onto lignin. These studies indicated that hydroxyl groups in lignin, especially phenolic $\mathrm{OH}$, played an essential role in cellulases-lignin interaction (Pan, 2008). Many other researchers later confirmed this hypothesis (Yu et al., 2014; Sun et al., 2016; Yao et al., 2017). It was found that hydroxypropylation of phenolic $\mathrm{OH}$ could reduce the negative inhibitory effect of lignin on cellulases (Yang and Pan, 2016). Similarly, pretreated biomass with decreased phenolic $\mathrm{OH}$ contributed to an increased digestibility of biomass (Mou and Wu, 2017). All these results support the hypothesis that hydrogen bonding plays a vital role in the nonproductive binding of cellulases to lignin.

The isoelectric point ( $\mathrm{pI}$ ) is a unique feature to each enzyme which is defined as the $\mathrm{pH}$ at which the overall net charge is zero. When the solution $\mathrm{pH}$ is above the $\mathrm{pI}$, the overall charge of the enzyme is negative, and vice versa. Cellulases and lignin will bind together if they possess opposite charges by electrostatic interactions. At $\mathrm{pH} 4.8$, which is the typical optimum $\mathrm{pH}$ of cellulases, lignin showed a negative zeta potential, and cellulases (such as Cel6A and Cel5A) were positively charged (Saini et al., 2016; Yang et al., 2020) while others (such as Cel7A and Cel7B) were negatively charged (Lai et al., 2018b). Thus, depends on the $\mathrm{pH}$ and the types of enzymes, there could be either attractive or repulsive forces between cellulase and lignin substrates. A study on the Trichoderma reesei cellulases cocktail and lignin showed that electrostatic interactions contributed to cellulases adsorption, and their effect was most pronounced for $\beta$-glucosidase from $T$. reesei (Ko et al., 2015a). An elevated $\mathrm{pH}$ in the cellulases hydrolysis process could significantly reduce the nonspecific binding of cellulases to lignin residues after various pretreatment (Lou et al., 2013). However, some studies in the literature report that electrostatic interactions were not significantly involved in the cellulases lignin interactions (Lou et al., 2013; Yang et al., 2020) which suggests further investigations are needed on this aspect.

\subsubsection{Deactivation of Cellulases by Lignin-Derived Phenolic Compounds}

As pretreatment is a necessary step to reduce the recalcitrance of biomass, lignin-derived phenolic compounds formed during pretreatment are nearly universal in the hydrolysate of pretreated lignocellulosic biomass. These soluble lignin derivatives could influence the performances of cellulases enzymes and fermentation yeast. The impacts of phenolics on yeast include damage to internal proteins structures, a decrease in cell growth, and changes in cell morphology (Fitzgerald et al., 2004). Studies showed that the properties of generated phenolics were significantly affected by the applied pretreatment technologies.

It has been confirmed that the phenols could inhibit cellulose hydrolysis. The rate of cellulose hydrolysis reduces by $50 \%$ by adding $8 \mathrm{mg}$ vanillin per FPU (Ximenes et al., 2010). Toxic and inhibitory compounds vary with applied pretreatment. Phenolics were identified as the most inhibitory components, which decreased the rate and extent of cellulose hydrolysis by half due to both inhibition and precipitation of the enzymes (Kim et al., 2011). The different influence of various phenolic compounds on cellulases and yeast might be due to the incorporation of amide group in phenolics which are formed during AFEX pretreatment process (Chen et al., 2020). Inhibition of different phenolics compounds on cellulases has been studied by Qin and his coauthors (Qin et al., 2016). It was found that phenolics compounds with aldehyde and ketone group exhibited a more inhibitory effect on cellulases than those with phenol and carboxyl group. In addition, the carbonyl group and methoxy group in phenolics also exhibited inhibition toward enzyme activity, as shown in Figure 4 (Qin et al., 2016). The effects of three phenolic acids on the structure of cellulases were also investigated. It was indicated that the addition of the phenolic acids (i.e., ferulic acid, $p$-coumaric acid, and salicylic acid) significantly changed the secondary structure of cellulases by decreasing $\alpha$-helix content, increasing $\beta$-sheet and random coil contents (Tian et al., 2013), which accounted for the decreased enzyme activity. Although lignin-derived phenolic compounds play negative effect on cellulases, as the hydrolysates have been separated from pretreated substrates, it may not affect the enzymatic hydrolysis process in some cases.

Most research studies have focused on the three lignin-enzyme interactions mentioned above, but not all three interactions were included in each enzyme adsorption mechanism study, as summarized in Table 2. In recent years, intriguing studies have shown that pretreated lignin from certain plant cell wall locations or with certain physicochemical properties could have a positive effect on the enzymatic hydrolysis process. For example, hardwood organosolv lignin was reported to enhance the enzymatic hydrolysis, while softwood organosolv lignin played a traditional negative role (Lai et al., 2014). Similarly, solvent extractable lignin and the residual bulk lignin also demonstrated distinct roles (Lai et al., 2015). Enhanced sugar release during hydrolysis was also reported by incorporating sulfonate groups (Wang et al., 2013a; Wang et al., 2013b; Zhou et al., 2013) and acid groups (Wu et al., 2011) onto the lignin during the biomass pretreatment step. Finally, Huang et al. concluded that the exact effect of lignin on enzymatic hydrolysis is a function of both inhibitive hydrophobic interactions and the stimulative electrostatic repulsions, which are controlled by lignin hydrophobicity and surface charges, respectively (Huang et al., 2017).

Although years of research on lignin-enzyme adsorption study has focused on using lignin model compound or modifying lignin structure in order to build the "structure-function" relationship, the relative contribution of each individual factors on ligninenzyme interaction is still unknow. This is mainly due to the difficulty of differentiating each driving forces and the lack of analytical techniques that could be used to directly measure these factors (Li and Zheng, 2017). For example, phenolic OH group from lignin has been proposed to contribute significantly to the hydrophobic interactions; however, these $\mathrm{OH}$ groups also affect 


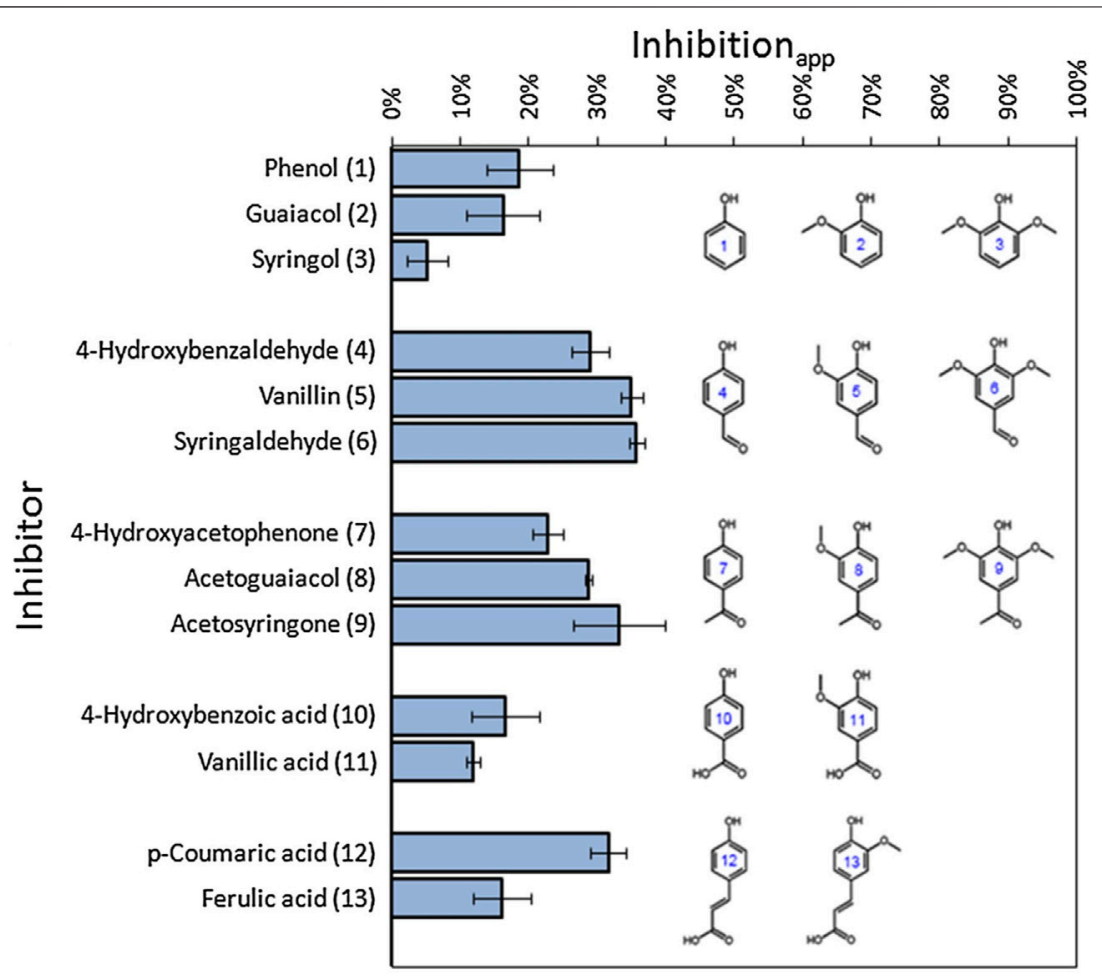

FIGURE 4 | Apparent inhibitions of different phenolic compounds on cellulases (Qin et al., 2016) Note: names and structures with the same number refer to the same phenolic compounds.

TABLE 2 | Mechanisms of nonproductive cellulases adsorption to lignin.

\begin{tabular}{|c|c|c|c|c|}
\hline Cellulases & Lignin & Adsorption conditions & Concluded mechanism & References \\
\hline $\begin{array}{l}\text { Celluclast } 1.5 \mathrm{~L} \text {, } \\
\text { Novozyme } 188\end{array}$ & $\begin{array}{l}\text { alkali lignin, hydrolytic lignin, organosolv lignin, } \\
\text { lignosulphonate acid sodium salt }\end{array}$ & $\begin{array}{l}\mathrm{pH} 4.8 \text {, at temperatures of } 4^{\circ} \mathrm{C} \\
\text { and } 45^{\circ} \mathrm{C}\end{array}$ & hydrophobic interactions & $\begin{array}{l}\text { Pareek et al. } \\
\text { (2013) }\end{array}$ \\
\hline Cellulase C2730 & $\begin{array}{l}\text { Isolated from hot water hydrothermal pretreated } \\
\text { aspen }\end{array}$ & $\begin{array}{l}2 \%(\mathrm{w} / \mathrm{w}) \text { lignin at } 4^{\circ} \mathrm{C} \text { and } 150 \mathrm{rpm} \\
\text { for } 2 \mathrm{~h}\end{array}$ & $\begin{array}{l}\text { Hydrophobic interactions, } \\
\text { hydrogen bonding }\end{array}$ & Sun et al. (2016) \\
\hline T. reesei $\beta$-glucosidase & $\begin{array}{l}\text { liquid hot water pretreated mixed hardwood } \\
\text { chips }\end{array}$ & $\mathrm{pH} 4.8$, at $25^{\circ} \mathrm{C}$ for $1.5 \mathrm{~h}$ & Electrostatic interactions & Ko et al. (2015a) \\
\hline $\begin{array}{l}\text { Cellobiohydrolase I, } \\
\text { endocellulase E1, eno-1,4-- } \\
\text { xylanase }\end{array}$ & $\begin{array}{l}\text { Extracted from switchgrass pretreated by methyl } \\
\text { isobutyl ketone, ethanol, water }(16 / 34 / 50 \mathrm{w} / \mathrm{w} / \\
\mathrm{w}), 0.1 \mathrm{M} \text { sulfuric acid at } 160^{\circ} \mathrm{C}\end{array}$ & $\begin{array}{l}1 \mathrm{mg} / \mathrm{ml} \text { of lignin, flowing enzyme } \\
\text { solution at } 0.1 \mathrm{ml} / \mathrm{min}\end{array}$ & $\begin{array}{l}\text { Hydrophobic interactions, } \\
\text { electrostatic interactions }\end{array}$ & $\begin{array}{l}\text { Sammond et al. } \\
\text { (2014) }\end{array}$ \\
\hline $\begin{array}{l}\text { Trichoderma reesei, ATCC } \\
26921\end{array}$ & $\begin{array}{l}\text { water-soluble, low sulfonate kraft lignin (MW = } \\
10,000)\end{array}$ & $\begin{array}{l}0.10 \mathrm{mg} / \mathrm{ml} \text { Celluclast at room } \\
\text { temperature in } \mathrm{pH} 4.8\end{array}$ & hydrophobic interaction & Qin et al. (2014) \\
\hline Cellic CTec2, CellulaseC2730 & $\begin{array}{l}\text { Ethanol organosolv lignin isolated from } \\
\text { organosolv pretreatment of cottonwood, black } \\
\text { willow, aspen, eucalyptus, and loblolly pine }\end{array}$ & $\begin{array}{l}2 \%(\mathrm{w} / \mathrm{v}) \mathrm{EOL} \text { lignins in } 0.05 \mathrm{M} \\
\text { citrate buffer ( } \mathrm{pH} 4.8) \text {, at } 4^{\circ} \mathrm{C} \text { and } \\
150 \mathrm{rpm} \text { for } 3 \mathrm{~h}\end{array}$ & $\begin{array}{l}\text { Hydrophobic interactions } \\
\text { and electrostatic interactions }\end{array}$ & $\begin{array}{l}\text { Huang et al. } \\
(2017)\end{array}$ \\
\hline $\begin{array}{l}\text { Trichoderma longibrachiatum } \\
\text { cellobiohydrolase }\end{array}$ & $\begin{array}{l}\text { lignin isolated from dilute acid pretreated } \\
\text { Broussonetia papyrifera }\end{array}$ & $\begin{array}{l}\text { lignins }(2 \%, w / v) \text { in acetate buffer } \\
(50 \mathrm{mM}, \mathrm{pH} 4.8) \text { at } 50^{\circ} \mathrm{C} \text { for } 4 \mathrm{~h}\end{array}$ & hydrogen bonding & Yao et al. (2017) \\
\hline $\begin{array}{l}\text { Trichoderma longibrachiatum } \\
\text { cellobiohydrolase }\end{array}$ & lignin isolated from dilute acid pretreated poplar & $\begin{array}{l}\text { lignin samples }(2 \%, w / v), p H \\
4.8 \text { at } 50^{\circ} \mathrm{C}\end{array}$ & hydrophobic interactions & $\begin{array}{l}\text { Yao et al. } \\
\text { (2018a) }\end{array}$ \\
\hline $\begin{array}{l}\text { Celluclast } 1.5 \mathrm{~L} \text { and } \\
\beta \text {-glucosidase }\end{array}$ & $\begin{array}{l}\text { enzymatic residual lignin treated with dilute } \\
\text { sulfuric acid at different severities }\end{array}$ & lignin $(1 \%, w / v)$, at $4^{\circ} \mathrm{C}$ for $1 \mathrm{~h}$ & hydrophobic interactions & $\begin{array}{l}\text { Wang et al. } \\
\text { (2020a) }\end{array}$ \\
\hline $\begin{array}{l}\text { Celluclast } 1.5 \mathrm{~L} \text { and } \\
\beta \text {-glucosidase }\end{array}$ & $\begin{array}{l}\text { enzymatic residual lignin treated with sodium } \\
\text { hydroxide at different severities }\end{array}$ & lignin $(1 \%, w / v)$ at $\mathrm{pH} 5.0$ and $50^{\circ} \mathrm{C}$ & $\begin{array}{l}\text { Hydrophobic interactions } \\
\text { and electrostatic interactions }\end{array}$ & $\begin{array}{l}\text { Wang et al. } \\
\text { (2020b) }\end{array}$ \\
\hline
\end{tabular}


TABLE 2 | (Continued) Mechanisms of nonproductive cellulases adsorption to lignin.

\begin{tabular}{|c|c|c|c|c|}
\hline Cellulases & Lignin & Adsorption conditions & Concluded mechanism & References \\
\hline $\begin{array}{l}\mathrm{CBH} \text { and BGL from Penicillium } \\
\text { oxalicum JU-A10-T }\end{array}$ & $\begin{array}{l}\text { Milled wood lignin from untreated and LHW } \\
\text { pretreated corn stover }\end{array}$ & $\begin{array}{l}50 \mathrm{mM} \text { acetate buffer }(\mathrm{pH} 4.8) \text { at } \\
50^{\circ} \mathrm{C} \text { for } 48 \mathrm{~h} \text { under } 50 \mathrm{rpm}\end{array}$ & Hydrophobic interactions & Lu et al. (2016) \\
\hline $\begin{array}{l}\text { EG and xylanase from } \\
\text { Penicillium oxalicum JU-A10-T }\end{array}$ & $\begin{array}{l}\text { Milled wood lignin from untreated and LHW } \\
\text { pretreated corn stover }\end{array}$ & $\begin{array}{l}50 \mathrm{mM} \text { acetate buffer }(\mathrm{pH} 4.8) \text { at } \\
50{ }^{\circ} \mathrm{C} \text { for } 48 \mathrm{~h} \text { under } 50 \mathrm{rpm}\end{array}$ & electrostatic interactions & Lu et al. (2016) \\
\hline Cellic CTec2 & lignin extracted from corn stover & $\begin{array}{l}\text { at room temperature for } 60 \mathrm{~min} \text { at } \\
\mathrm{pH} 4.8\end{array}$ & $\begin{array}{l}\text { hydrophobic and } \\
\text { electrostatic interactions }\end{array}$ & $\begin{array}{l}\text { Yarbrough et al } \\
\text { (2015) }\end{array}$ \\
\hline
\end{tabular}

lignin's hydrogen bonding ability which is difficult to measure directly. Additional work is much needed to resolve these challenges.

\section{FACTORS INFLUENCING LIGNIN-CELLULASES INTERACTIONS FROM A LIGNIN PERSPECTIVE}

\subsection{Lignin Transformation During Pretreatment and Its Effect on Cellulases Interaction}

\subsubsection{Dilute Acid Pretreatment}

Dilute acid pretreatment is a widely studied pretreatment method which typically exhibits limited delignification. Studies showed that the inhibitory effect of lignin from DA pretreated biomass was more significant than the untreated one (Xu et al., 2020). It is well known that both polymerization and depolymerization can happen during acid-catalyzed pretreatment (Schutyser et al., 2018; Yang et al., 2020). During DA pretreatment, lignin has been reported to be significantly depolymerized by acid catalyzed hydrolysis of $\beta$-O-4 linkages as reported in several earlier studies (Lundquist et al., 1972; Karlsson et al., 1988). Usually, the molecular weight of lignin after DA pretreatment was decreased (Yang et al., 2020), and the lower molecular weight favored CBH (Cellobiohydrolase I) adsorption to lignin (Yao et al., 2018a). Poplar lignin was only partially degraded after DA pretreatment at $170^{\circ} \mathrm{C}$ for 8 min using $0.5 \% \mathrm{H}_{2} \mathrm{SO}_{4}$ as catalyst (Hu et al., 2013). Structural analysis of milled wood lignin from switchgrass after DA pretreatment showed that the $\beta-\mathrm{O}-4, \beta-\beta$, $\beta$-5 linkages, and syringyl units were all decreased (Samuel et al., 2010). By comparing four different pretreatment methods (including dilute sulfuric acid, sodium hydroxide, ethanol, hot liquid water) on the structural features of residual lignin and their impact on cellulases, the results indicated that dilute sulfuric acid pretreated lignin showed the maximum adsorption capacity to cellulases (Xu et al., 2020). The reason might due to the lowest negative zeta potential of residual lignin after dilute sulfuric acid pretreatment.

The condensation reaction is another important lignin transformation during DA pretreatment (Samuel et al., 2010; Imai et al., 2011; Cao et al., 2012; Moxley et al., 2012; Pu et al.,

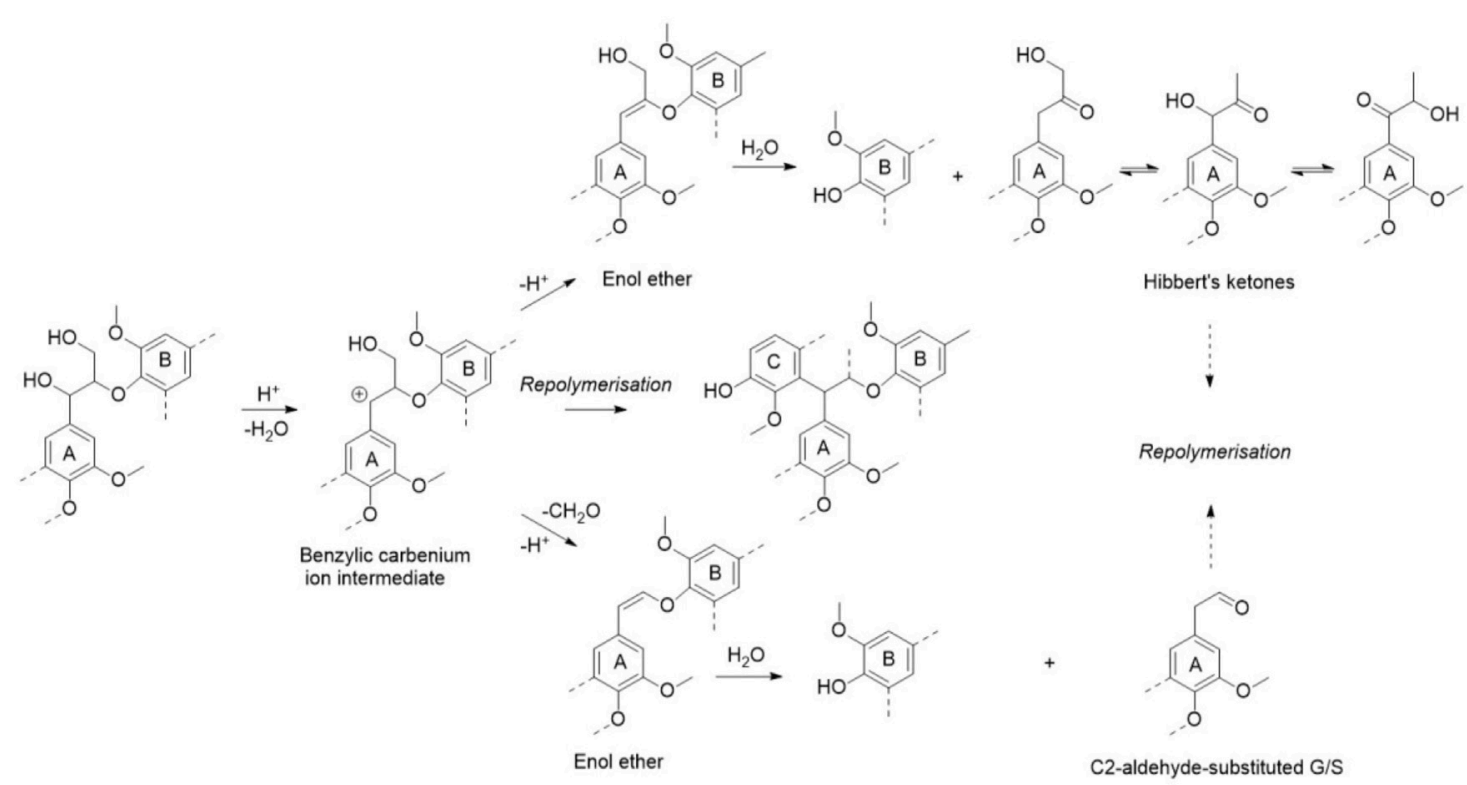

FIGURE 5 | Acid-catalyzed lignin chemistry (Schutyser et al., 2018). 


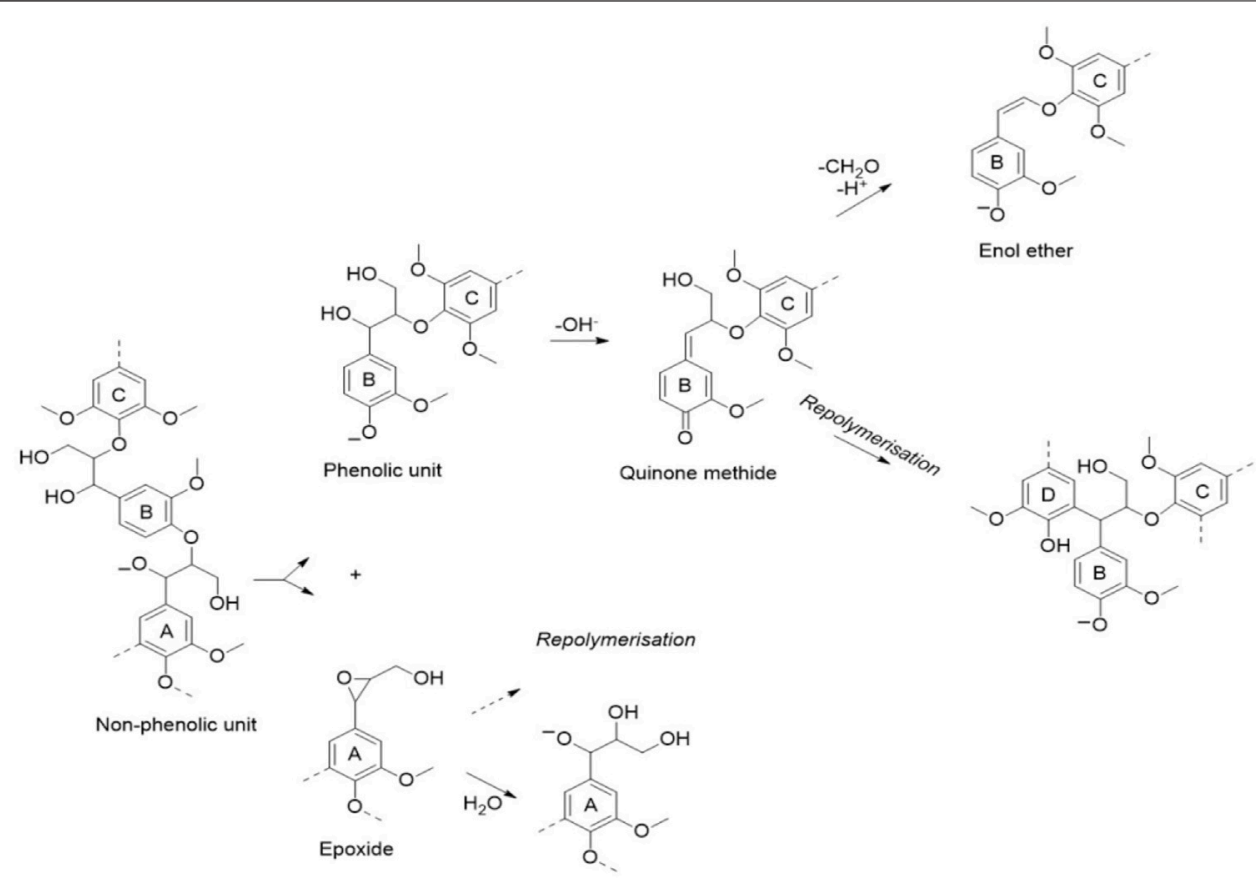

FIGURE 6 | Base-catalyzed lignin chemistry (Schutyser et al., 2018).

2013; Deuss et al., 2015; Sun et al., 2015; Ko et al., 2015b), which could cause increased cellulases adsorption to lignin (Yao et al., 2018a). The formation of condensed lignin process is depicted in Figure 5. Depending on the applied acid, the formation of a benzylic carbonium ion could be transformed into two enol ether structures. Subsequent hydrolysis products of the acid-labile enol ethers could participate in a complex network of repolymerization reactions, resulting in a condensed lignin polymer. It was found that the addition of formaldehyde during pretreatment can partly prevent lignin condensation. The resulting stable 1,3-dioxane structure with the 1,3-diols on lignin side-chains could enhance the amount of uncondensed lignin by blocking the formation of benzylic cations after pretreatment (Shuai et al., 2016a), which was later verified by other researchers (Zhang et al., 2021). Furthermore, 2-naphthol and 2-naphthol-7-sulfonate additives were employed during DA pretreatment to block lignin bridging reactions and consequently, improved cellulases hydrolysis yield by 47.8\% (Lai et al., 2018a).

Another impact of DA pretreatment on cellulases was caused by the formation of pseudo-lignin (Wan et al., 2019), which was shown to be more detrimental to enzymatic hydrolysis of cellulose than residual lignin ( $\mathrm{Hu}$ et al., 2012; He et al., 2018; Wang and Jönsson, 2018). Several studies demonstrated that the pseudo-lignin was a polyaromatic (i.e., lignin-like) structural substances derived from carbohydrate degradation products (Sannigrahi et al., 2011) which increased the Klason lignin content after DA (Shinde et al., 2018; Wang and Jönsson, 2018). A recent study revealed that soluble lignin model compounds could participate in pseudo-lignin's formation during acid pretreatment by assembling a platform of spherical droplets (He et al., 2020b). As pseudo-lignin is typically formed at high pretreatment severity, thus, severe conditions should be avoided during DA pretreatment.

\subsubsection{Alkaline Pretreatment}

A review of the alkaline $(\mathrm{AL})$ pretreatment literature indicates that different bases (e.g., $\mathrm{NaOH}$ and lime) could be used in $\mathrm{AL}$ pretreatment for lignin solubilization (Yang and Pan, 2016). These kinds of AL based pretreatments are usually carried out at lower temperature and pressure when compared with hydrothermal pretreatments (Fang et al., 2018). NaOH-based pretreatment could reduce biomass recalcitrance by rupturing the linkages between lignin and polysaccharides (mainly hemicellulose), degrading $\beta$-O-4 linkages, cleaving ester bonds, as well as disrupting the lignin structure (Xiao et al., 2014; Yan et al., 2015; Yang et al., 2016). Base-catalyzed cleavage of the $\beta$-O4 bonds in non-phenolic units has been postulated to produce an epoxide intermediate and a phenolic unit that could be transformed into quinone methides (Figure 6). The quinone methide can repolymerize via the formation of a carbon-carbon bond (Schutyser et al., 2018). Alternatively, the removal of the terminal $\gamma-\mathrm{CH}_{2} \mathrm{OH}$ group could form an alkali-stable enol ether motif and formaldehyde.

In addition to $\mathrm{NaOH}$-based techniques, ammonia fiber explosion/expansion (AFEX) is another well-known alkaline pretreatment (Bouxin et al., 2015). Cleavage of LCC and ester linkages during the pretreatment process could result in partial solubilization of lignin, which is mainly composed of oligomeric fragments, and $\beta-\mathrm{O}-4$ bonds are typically well preserved during the ammonia based pretreatment (Chundawat et al., 2011).

Our previous research indicated that lignin could be easily dissolved during $\mathrm{AL}$ pretreatment, and the recovered lignin 


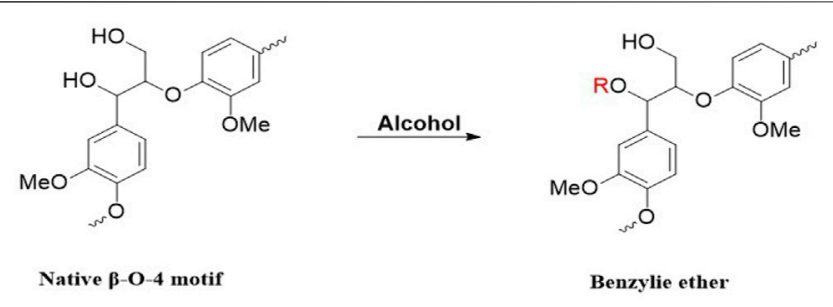

FIGURE 7 | $a$-esterification of lignin during alcohol pretreatment, R represents different tail with applied alcohol (Dong et al., 2019).

termed as alkaline lignin showed the least effect on cellulases performance when compared with milled wood lignin and Klason lignin (Yao et al., 2012). Hydrophilic sulfonated lignin and hydrophobic kraft lignin were compared of their effects on the enzymatic digestibility of various pretreated biomass. The impact of lignin addition on the enzymatic digestibility varied with both added lignin type and the applied pretreatment methods (Wang et al., 2015a). It was implied that the influence of lignin addition on the enzymatic digestibility of pretreated biomass was dependent not only on the properties of introduced lignin, but on the residual lignin in pretreated biomass as well. By comparing alkali lignins with different molecular weights on enzymatic hydrolysis of lignocellulose, it was showed that the addition of alkali lignins improved the cellulases hydrolysis, and it was increased with increasing molecular weights of alkali lignins (Li Y. et al., 2016). Due to the adsorption of cellulases on alkali lignins, the filter paper activity could be enhanced. Another study demonstrated that when kraft pine lignin was precipitated on the surface of cellulose, a detrimental effect on the hydrolysis performance of enzymes was noted (Li W. et al., 2018). Kraft pine lignin with different molecular weights showed that lignin of lower molecular weight might form a complex with cellulases, and lignin of higher molecular weight resulted in steric repulsions by lignin deposition on cellulose (Li W. et al., 2018). By comparing residual lignins in acid pretreated and kraft pulped bamboo, their extents of nonproductive enzyme adsorption were investigated. It was found that the maximum adsorption capacity and the inhibitory effect on enzymatic hydrolysis efficiency was more obvious in acid pretreated lignin than kraft pulped bamboo lignin (Huang et al., 2016), due to more hydrophobicity, phenolic hydroxyl group, and the degree of condensation of residual lignin after dilute acid pretreatment.

\subsubsection{Organosolv Pretreatment}

Organosolv (OS) pretreatment is a well-known delignification method employing various organic solvents including acetone, methanol, ethanol, diol, THF, and $\gamma$-Valerolactone (GVL). Lignin could be substantially removed due to the acid catalyzed cleavage of $\beta$-aryl ether bonds (Kangas et al., 2015) resulting in a celluloserich solid residual with enhanced reactivity toward enzymes (Zhang et al., 2016; Dong et al., 2019; Meng et al., 2020). The advantage of OS pretreatment includes the enhanced digestibility of pretreated biomass and the high potential valorization ability of the obtained organosolv lignin (García et al., 2017; Sadeghifar et al., 2017; Yao et al., 2020).
Ethanol is the most studied green solvent applied in organosolv pretreatment. Structural analysis of lignin from Populus after auto-catalyzed ethanol organosolv pretreatment indicated that part of the $\beta-\mathrm{O}-4^{\prime}$ linkages were cleaved whereas, $\beta-\beta^{\prime}$ and $\beta-5^{\prime}$ units were intact. Stilbene units were also formed during this process (Guo et al., 2015). It was also observed that ethanol organosolv resulted in an increase in the S/G ratio, cleavage of part of $\beta-\mathrm{O}-4^{\prime}$ and $\beta-5$ ' (Sannigrahi et al., 2009; Hallac et al., 2010; Wen et al., 2013; Zhu et al., 2015; Rinaldi et al., 2016; Yao et al., 2018b). Furthermore, organic solvents such as ethanol and methanol have been reported to quench the benzyl carbonation intermediate by forming ether linkages at the a position of lignin (Mateo et al., 2020), which could hinder lignin repolymerization and condensation (Huang et al., 2015).

A modified organosolv pretreatment employing 1,4-butanediol (1,4-BDO) was developed by Dong and his coworkers (Dong et al., 2019). The results showed that lignin deposition was not formed compared with conventional organosolv pretreatment using ethanol, and a relatively higher amount of $\beta-\mathrm{O}-4$ ' interunit linkages was retained in residual lignin by forming $\alpha$-etherified lignin with hydroxyl tail and protecting the $\beta-\mathrm{O}-4$ substructure from degradation and condensation, shown in Figure 7 (Dong et al., 2019). In another study, by applying ethanol (EtOH), THF, and $\gamma$-Valerolactone (GVL), it was found that the total content of condensed $\mathrm{S}$ and $\mathrm{G}$ units was significantly higher in EtOH lignin than that in THF and GVL lignins. Furthermore, more $\beta-\mathrm{O}-4$ linkage was preserved in GVL lignin, making it suitable for producing mono-aromatic lignin compounds (Shuai et al., 2016b; Meng et al., 2020). Similar to GVL, cyrene, a cellulosederived aprotic dipolar organic solvent, also has high potential as a green pretreatment solvent in terms of lignin fractionation/ recovery and sugar release in the follow-up enzymatic hydrolysis (Meng et al., 2020b).

Various co-solvent pretreatments have demonstrated advantages relative to aqueous-only methods by enhancing lignin removal, among which tetrahydrofuran (THF) has been identified as a highly effective co-solvent for solubilizing and extracting lignin from biomass by adopting extended coil configurations (Smith et al., 2016). Not only enhanced solubilization of cellulose and high yields of fermentable sugars can be achieved by the THF-water co-solvent system (Mostofian et al., 2016), but also facilities lignin transformation into valuable chemical precursors (Patri et al., 2019).

Lai and her coauthors found positive effects of extractable lignin (EL) on enzymatic hydrolysis of ethanol organosolvpretreated wood sawdust by blocking nonproductive enzyme binding sites on the milled wood lignin (Lai et al., 2019). Subsequent research found that different organosolv lignin showed disparate effects on cellulases. It was indicated that organosolv lignin with PB units enhanced MCC digestibility (Huang Y. et al., 2020). The reason is because the partial negative charges on the carbonyl groups in $\mathrm{PB}$ units result in lower cellulases binding on lignin. Acid-catalyzed glycerol (AG) pretreatment of sugarcane bagasse was investigated and it was found that glycerol had modified the bagasse lignin through a-etherification of $\beta$-aryl ethers and $\gamma$-esterification of 
hydroxycinnamic acids. The obtained lignin was highly hydrophilic, and it did not inhibit the enzymatic hydrolysis of pretreated bagasse (Hassanpour et al., 2020). By comparing liquid-hot-water (LHW) pretreatment with acid-free ethanolwater (EW) pretreatment, it was found that the nonproductive adsorption between EW pretreatment-induced lignin and cellulases was significantly weakened due to the advantages of suppressing the deposition of lignin condensates (Shi et al., 2018).

\subsubsection{Other Promising Pretreatments}

As new and rapid emerging green solvents, deep eutectic solvents (DESs) have gained much attention lately, which are composed of a hydrogen-bond acceptor (HBA) and a hydrogen-bond donor (HBD) component. In addition, DESs are biocompatible, nontoxic, and have been shown to be recycled for at least 5 rounds in pretreatment with the same digestibility improvement (Kim et al., 2018; Li A-L. et al., 2018; Guo et al., 2019; Kim et al., 2019; Kim et al., 2019; Sai and Lee, 2019; Song et al., 2019; Lin et al., 2020; Huang et al., 2021; Ji et al., 2021). Compared with dilute acid and alkaline pretreatment, DES pretreatment led to significantly higher lignin removal (Li A-L. et al., 2018; Li W-X. et al., 2021; Tan et al., 2019; Guo et al., 2018; Hansen et al., 2021; Fernandes et al., 2021). The central lignin transformation during DES pretreatment of wood lignin was the cleavage of $\beta-\mathrm{O}-4$ linkages, resulting in decreased molecular weight and increased hydroxyl groups (Das et al., 2018; Kim et al., 2019; Wang J. et al., 2020; Wang Y. et al., 2020; Wang Y. et al., 2021). Similar research also proved that acidic DESs could degrade a small portion of $\mathrm{C}-\mathrm{C}$ bonds in lignin (Li A-L. et al., 2018; Ma et al., 2021). In addition to depolymerization, repolymerization of lignin fractions can also occur during acidic DES pretreatment via acid-catalyzed recondensation (Liu et al., 2021). Alkaline DES pretreatment disrupts lignin-carbohydrate compounds and breaks ether linkages in lignin (Ho et al., 2019). Studies indicated that acidic DESs showed higher lignin solubility than alkaline DESs, and lignin from bamboo dissolved in DES was mainly syringyl lignin (Li C. et al., 2021). DES-extracted lignin from willow and corn stover showed an inhibitory effect on cellulases by hydrophobic interactions and hydrogen bonds (Song et al., 2020).

Acid hydrotropic fractionation (AHF) was another promising method developed by Zhu's group to improve lignin valorization by reducing lignin condensation (Chen et al., 2017). AHF refers to fractionate lignocelluloses using a group of acids with hydrotropic properties (Cai et al., 2020). It was suggested that acid hydrotrope could aggregate around extracted lignin to prevent lignin from aggregation (Ji and Lv, 2020). The impact of the hydrotropy on ether and/or ester bonds cleavage can promote the removal of lignin from the plant cell wall. Results indicated that lignin carboxylation during pretreatment could improve glucose yield during the saccharification process by reducing nonproductive cellulases adsorption to lignin (Cai et al., 2020). Furthermore, maleic acid pretreated switchgrass showed improved enzymatic digestiblity by carboxylated lignin and cellulose in the fractionated cellulosic water-insoluble solids (Su et al., 2021).

Due to the limitation of each pretreatment method, combined pretreatment technologies have been developed. As early as 2012, deacetylation with $0.1 \mathrm{M} \mathrm{NaOH}$ before acid pretreatment was suggested by Chen and his co-workers to improve the monomeric sugar yield and minimum ethanol selling price (Chen et al., 2012). Two-stage hydrothermal pretreatment was proposed by Min et al. to diminish inhibitors and enhance the total sugar recovery at the same time (Min et al., 2015). Then, combinatorial pretreatment with $1 \% \mathrm{H}_{2} \mathrm{SO}_{4}$ for $30 \mathrm{~min}$ followed by $1 \% \mathrm{NaOH}$ for $60 \mathrm{~min}$ at $120^{\circ} \mathrm{C}$ of corn stover were investigated in an effort to synergistically improve carbohydrate conversion and lignin processability into polyhydroxyalkanoate (Liu et al., 2017). Similarly, a highlighted application of combinatorial pretreatments of autohydrolysis followed by dilute alkali extraction was applied by Huang and his coworkers to maximize the carbohydrate output from bamboo (Huang C. et al., 2020). Furthermore, combination pretreatment using dilute sulfuric acid, liquid hot water, sodium hydroxide, and ethanol were developed by the same research group (Liu et al., 2018). Results showed that combinatorial pretreatment was an effective strategy to facilitate lignin valorization. In an effort to efficiently produce sugars and improve lignin processability for the fabrication of lignin nanoparticles, combinatorial organosolv pretreatment (COP) was thus developed (Liu Z-H. et al., 2019).

Sulfite pretreatment to overcome recalcitrance of lignocellulose (SPORL) is another combined pretreatment technology which consists of sulfite pretreatment with acid catalyst followed by mechanical refining (Zhu et al., 2009). SPORL-treated softwood chips were significantly softened and over $90 \%$ of enzymatic cellulose conversion could be obtained (Zhu et al., 2009). It was indicated that hemicellulose removal and lignin sulfonation during SPORL were beneficial for the following cellulose hydrolysis process (Zhu et al., 2009). When applied to a hardwood, near complete cellulose conversion to glucose could be achieved with only about $4 \%$ sodium bisulfite charge on aspen at $180^{\circ} \mathrm{C}$ for 30 min (Wang et al., 2009). Afterwards, by comparing SPORL with dilute acid (DA) pretreatments, it was found that higher enzymatic digestibility and ethanol yield were produced after SPORL than DA pretreated wood chips (Tian et al., 2011). More effective in xylan removal and decreased extent of lignin condensation during SPORL might explain this observation. Furthermore, lower amount of furfural and HMF were formed, which was favorable for the following yeast fermentation (Tian et al., 2011).

Fenton oxidation is an environmental friendly process operated under mild conditions (Zhang et al., 2018). Lignin and hemicellulose could be degraded during the process, which enhances the enzymatic hydrolysis subsequently (Wang S. et al., 2021). To further explore ultrasound-assisted Fenton reaction, it was compared with dilute acid-catalyzed steam explosion. Results showed that ultrasoundassisted Fenton reaction removed more lignin and created slightly more accessible area and pores on the surface of the substrate compared with dilute acid-catalyzed steam explosion (Wang et al., 2016). During Fenton pretreatment, C1 of cellulose was oxidized, which plays an important role in improving enzymatic hydrolysis by making cellulose more accessible (Yang et al., 2019). In addition, lignin structure was transformed after Fenton pretreatment. The S/G and phenolic $\mathrm{OH}$ group content were decreased, while the carboxylic content and the negative zeta potential were increased, all of which might be the reason for 
decreased unproductive adsorption of cellulases on lignin compared with untreated milled bamboo lignin (Wu et al., 2018).

Furthermore, sequential Fenton oxidation and sulfomethylation pretreatment was applied to increase the enzymatic accessibility by $20 \%$ after pretreatment. Fenton oxidative reaction could help introduce sulfomethyl group on aromatic ring more easily by oxidative demethylation, cleave some interunit linkages and increase the hydrophilicity of residual lignin (Ying et al., 2019). Two-pot sequential pretreatment, comprising of ultrasound ethanol and deep eutectic solvent, was developed to efficiently fractionate lignocellulosic biomass into cellulose with high digestibility and high-quality lignin with tailored chemical structures (Ji et al., 2021).

Reductive catalytic fractionation (RCF) has emerged in the past few years to pursue value-added lignin derived products and a cellulose-rich residue that could be further converted to its sugar monomers (Korányi et al., 2020). The key steps include solvolytic extraction, catalytic degradation and upgrading of lignin (Liu et al., 2020). Many different feedstocks (softwood, hardwood and Gramineae), catalysts (Raney-Ni, Zn-Pd/C, Pd/C, $\mathrm{Ru} / \mathrm{C}, \mathrm{Ni} / \mathrm{C}, \mathrm{Ni}_{2} \mathrm{P} / \mathrm{SiO}_{2}, \mathrm{Ni} @ \mathrm{ZIF}-8$ ) and process (solvent, temperature, pressure and time, one-pot method, two-step method) have been investigated to obtain various value-added lignin derived phenolic chemicals up till now (Ferrini and Rinaldi, 2014; Parsell et al., 2015; Schutyser et al., 2015; Luo et al., 2016; Shuai et al., 2016a; Anderson et al., 2017; Cao et al., 2018; Graça et al., 2018; Liu X. et al., 2019). Recently, hydrogenolysis of lignin in birch sawdust with the selectivity towards 4-propyl guaiacol and 4-propyl syringol was achieved with noble metal based catalysts of $5 \% \mathrm{Ru} / \mathrm{C}$ (Liu et al., 2020). A low-cost $\mathrm{MoO}_{2} / \mathrm{C}$ catalyst was prepared for the RCF of biomass feedstocks, with high selectivity towards methyl coumarate and methyl ferulate (Gong et al., 2021). Effective removal of the catalyst from the pretreatment residue to enable subsequent enzymatic hydrolysis will be essential for the efficient biofuel production and catalyst recycle at industrial scale.

\subsection{Interactions Between Lignin and Cellulases by Model Compounds}

Until now, often conflicting conclusion have been reported on the impact and the underlying mechanisms of lignin on cellulases and its hydrolysis properties. It is challenging to investigate the impact of a single lignin feature on cellulases, as any change will result in a concurrent change in other lignin properties. Thus, model compounds are a useful tool in the mechanism study. Homodimers of guaiacyl (LGG) were used as a representative to predict lignin binding sites of $\beta$-glucosidases by AutoDock (Lu et al., 2017). Based on the predicted results, the adsorption of the CBM onto lignin was decreased by altering the charge properties of amino acid in $\mathrm{CBH}$, indicating the feasibility of model compounds' application in the mechanism research. Three types of ${ }^{13} \mathrm{C}$-labeled $\beta$-O-4 lignin oligomer models were then synthesized and applied in binding sites research of Cellobiohydrolase I (Cel7A) in lignins by Tokunaga and his coworkers (Tokunaga et al., 2020). To explore the effect of lignin composition on cellulases adsorption, H-DHP, G-DHP, and S-DHP (dehydrogenation polymers) were prepared. The results clearly showed that lignin composition had a significant impact on cellulases performance, and that G-type lignin exhibited the most detrimental effect (Yao et al., 2021). With the development of synthetic chemistry, lignin models with higher molecular weight would simulate further investigations into the lignincellulases adsorption process with more conclusive results.

\subsection{Decrease Nonproductive Adsorption by Additives}

Lignin-blocking additives, such as bovine serum albumin, soybean protein, and surfactants, have been applied in the enzymatic hydrolysis process to improve glucose yields (Kim et al., 1982; Yang and Wyman, 2006; Selig et al., 2008; Mukasekuru et al., 2018; Bhagia et al., 2019; Florencio et al., 2019; Luo et al., 2020). It was reported that these additives could improve glucose release by cellulases treatment by binding to lignin, thus decreased nonproductive cellulases adsorption to lignin (Borjesson et al., 2007; Zheng et al., 2008). Furthermore, biomass washing combined with soybean protein addition was evaluated recently on glucose release during the enzymatic hydrolysis process, which is cost-competitive in a large-scale industrial process (Pinto et al., 2021).

\section{PERSPECTIVE FOR FUTURE CHALLENGES OF LIGNIN IN BIOREFINERY PROCESS}

Lignin is expected to play an essential role in the future integrated biorefinery process and the development of renewable chemicals and biomaterials. The mechanism underlying cellulases adsorption to lignin has not been fully elucidated so far, mainly due to the complex structure of enzymes, and the heterogeneity of lignin which was also the cause for undesirable lignin performances of particular applications (Yoo et al., 2020).

The unique biosynthesis of lignin causes the initial heterogeneity of this biopolymer. Furthermore, most pretreatments result in an increase the structural heterogeneity of lignin. The depolymerization/repolymerization of lignin during the pretreatment often increase the polydispersity of lignin molecular weight. Future pretreatment methods that decrease the heterogeneity of lignin might favor the following enzymatic hydrolysis process.

The application of recovered lignin from pretreatment is vital to the biorefinery process. It was reported that over-cleavage of $\beta-\mathrm{O}-4$ linkages to yield more dissolved lignin could damage the lignin's structure for future lignin valorization (Dong et al., 2019). Promising pretreatment should offer a reaction pathway for lignin structural integrity and enhanced cellulose digestibility simultaneously.

\section{AUTHOR CONTRIBUTIONS}

All authors listed have made a substantial, direct, and intellectual contribution to the work and approved it for publication. 


\section{ACKNOWLEDGMENTS}

The authors are grateful for the support from the National Natural Science Foundation of China (No. 21978074 and 31871789), the China Scholarship Council (No. 2011842330 and 201508420257).

\section{REFERENCES}

Anderson, E. M., Stone, M. L., Katahira, R., Reed, M., Beckham, G. T., and RománLeshkov, Y. (2017). Flowthrough Reductive Catalytic Fractionation of Biomass. Joule 1, 613-622. doi:10.1016/j.joule.2017.10.004

Araya, F., Troncoso, E., Mendonca, R. T., and Freer, J. (2015). Condensed Lignin Structures and Re-Localization Achieved at High Severities in Autohydrolysis of Eucalyptus globulus Wood and Their Relationship With Cellulose Accessibility. Biotechnol. Bioeng. 112, 1783-1791. doi:10.1002/bit.25604

Bhagia, S., Wyman, C. E., and Kumar, R. (2019). Impacts of Cellulase Deactivation at the Moving Air-Liquid Interface on Cellulose Conversions at Low Enzyme Loadings. Biotechnol. Biofuels 12, 96-110. doi:10.1186/s13068-019-1439-2

Börjesson, J., Peterson, R., and Tjerneld, F. (2007). Enhanced Enzymatic Conversion of Softwood Lignocellulose by Poly(ethylene Glycol) Addition. Enzyme Microb. Technol. 40, 754-762. doi:10.1016/j.enzmictec.2006.06.006

Bouxin, F. P., McVeigh, A., Tran, F., Westwood, N. J., Jarvis, M. C., and Jackson, S. D. (2015). Catalytic Depolymerisation of Isolated Lignins to fine Chemicals Using a Pt/alumina Catalyst: Part 1-impact of the Lignin Structure. Green. Chem. 17, 1235-1242. doi:10.1039/c4gc01678e

Cai, C., Hirth, K., Gleisner, R., Lou, H., Qiu, X., and Zhu, J. Y. (2020). Maleic Acid as a Dicarboxylic Acid Hydrotrope for Sustainable Fractionation of wood at Atmospheric Pressure and $\leq 100{ }^{\circ} \mathrm{C}$ : Mode and Utility of Lignin Esterification. Green. Chem. 22, 1605-1617. doi:10.1039/C9GC04267A

Cao, S., Pu, Y., Studer, M., Wyman, C., and Ragauskas, A. J. (2012). Chemical Transformations of Populus trichocarpa during Dilute Acid Pretreatment. RSC Adv. 2, 10925-10936. doi:10.1039/C2RA22045H

Cao, Z., Dierks, M., Clough, M. T., Daltro de Castro, I. B., and Rinaldi, R. (2018). A Convergent Approach for a Deep Converting Lignin-First Biorefinery Rendering High-Energy-Density Drop-In Fuels. Joule 2, 1118-1133. doi:10.1016/j.joule.2018.03.012

Chen, X., Tao, L., Shekiro, J., Mohaghaghi, A., Decker, S., Wang, W., et al. (2012). Improved Ethanol Yield and Reduced Minimum Ethanol Selling Price (MESP) by Modifying Low Severity Dilute Acid Pretreatment with Deacetylation and Mechanical Refining: 1) Experimental. Biotechnol. Biofuels 5, 60-69. doi:10.1186/1754-6834-5-60

Chen, L., Dou, J., Ma, Q., Li, N., Wu, R., Bian, H., et al. (2017). Rapid and NearComplete Dissolution of wood Lignin at $\leq 80^{\circ} \mathrm{C}$ by a Recyclable Acid Hydrotrope. Sci. Adv. 3, e1701735. doi:10.1126/sciadv.1701735

Chen, X., Zhai, R., Li, Y., Yuan, X., Liu, Z.-H., and Jin, M. (2020). Understanding the Structural Characteristics of Water-Soluble Phenolic Compounds from Four Pretreatments of Corn stover and Their Inhibitory Effects on Enzymatic Hydrolysis and Fermentation. Biotechnol. Biofuels 13, 44-56. doi:10.1186/ s13068-020-01686-z

Chundawat, S. P. S., Donohoe, B. S., da Costa Sousa, L., Elder, T., Agarwal, U. P., Lu, F., et al. (2011). Multi-scale Visualization and Characterization of Lignocellulosic Plant Cell wall Deconstruction during Thermochemical Pretreatment. Energy Environ. Sci. 4, 973-984. doi:10.1039/c0ee00574f

Cole-Hamilton, D. (2020). The Role of Chemists and Chemical Engineers in a Sustainable World. Chem. Eur. J. 26, 1894-1899. doi:10.1002/chem.201905748

Das, L., Li, M., Stevens, J., Li, W., Pu, Y., Ragauskas, A. J., et al. (2018). Characterization and Catalytic Transfer Hydrogenolysis of Deep Eutectic Solvent Extracted Sorghum Lignin to Phenolic Compounds. ACS Sustain. Chem. Eng. 6, 10408-10420. doi:10.1021/acssuschemeng.8b01763

Deuss, P. J., Scott, M., Tran, F., Westwood, N. J., de Vries, J. G., and Barta, K. (2015). Aromatic Monomers by In Situ Conversion of Reactive Intermediates in the Acid-Catalyzed Depolymerization of Lignin. J. Am. Chem. Soc. 137, 7456-7467. doi:10.1021/jacs.5b03693
MZ was supported by University of Tennessee and AR acknowledges the support of the Genomic Science Program, Office of Biological and Environmental Research (OBER), U. S. Department of Energy (DOE), under contract FWP ERKP752 for this research.

Ding, S.-Y., Liu, Y.-S., Zeng, Y., Himmel, M. E., Baker, J. O., and Bayer, E. A. (2012). How Does Plant Cell Wall Nanoscale Architecture Correlate with Enzymatic Digestibility? Science 338, 1055-1060. doi:10.1126/science.1227491

Dong, C., Meng, X., Yeung, C. S., Tse, H.-Y., Ragauskas, A. J., and Leu, S.-Y. (2019). Diol Pretreatment to Fractionate a Reactive Lignin in Lignocellulosic Biomass Biorefineries. Green. Chem. 21, 2788-2800. doi:10.1039/C9GC00596J

Donohoe, B. S., Decker, S. R., Tucker, M. P., Himmel, M. E., and Vinzant, T. B. (2008). Visualizing Lignin Coalescence and Migration through maize Cell walls Following Thermochemical Pretreatment. Biotechnol. Bioeng. 101, 913-925. doi:10.1002/bit.21959

Fang, S., Wang, W., Tong, S., Zhang, C., and Liu, P. (2018). Evaluation of the Effects of Isolated Lignin on Cellulose Enzymatic Hydrolysis of Corn Stover Pretreatment by $\mathrm{NaOH}$ Combined with Ozone. Molecules 23, 1495-1508. doi:10.3390/molecules23061495

Fernandes, C., Melro, E., Magalhães, S., Alves, L., Craveiro, R., FilipeValente, A. J. M., et al. (2021). New Deep Eutectic Solvent Assisted Extraction of Highly Pure Lignin from Maritime pine Sawdust (Pinus pinaster Ait.) Int. J. Biol. Macromol. 177, 294-305. doi:10.1016/j.ijbiomac.2021.02.088

Ferrini, P., and Rinaldi, R. (2014). Catalytic Biorefining of Plant Biomass to Nonpyrolytic Lignin Bio-Oil and Carbohydrates through Hydrogen Transfer Reactions. Angew. Chem. Int. Ed. 53, 8634-8639. doi:10.1002/anie.201403747

Fitzgerald, D. J., Stratford, M., Gasson, M. J., Ueckert, J., Bos, A., and Narbad, A. (2004). Mode of Antimicrobial Action of Vanillin against Escherichia coli, Lactobacillus Plantarum and Listeria Innocua. J. Appl. Microbiol. 97, 104-113. doi:10.1111/j.1365-2672.2004.02275.x

Florencio, C., Badino, A. C., and Farinas, C. S. (2019). Addition of Soybean Protein Improves Saccharification and Ethanol Production from Hydrothermally Pretreated Sugarcane Bagasse. Bioenerg. Res. 12, 81-93. doi:10.1007/s12155018-9956-6

García, A., Spigno, G., and Labidi, J. (2017). Antioxidant and Biocide Behaviour of Lignin Fractions from Apple Tree Pruning Residues. Ind. Crops Prod. 104, 242-252. doi:10.1016/j.indcrop.2017.04.063

Gong, X., Sun, J., Xu, X., Wang, B., Li, H., and Peng, F. (2021). Molybdenumcatalyzed Hydrogenolysis of Herbaceous Biomass: A Procedure Integrated Lignin Fragmentation and Components Fractionation. Bioresour. Technol. 333, 124977-124983. doi:10.1016/j.biortech.2021.124977

Graça, I., Woodward, R. T., Kennema, M., and Rinaldi, R. (2018). Formation and Fate of Carboxylic Acids in the Lignin-First Biorefining of Lignocellulose via H-Transfer Catalyzed by Raney Ni. ACS Sustain. Chem. Eng. 6, 13408-13419. doi:10.1021/acssuschemeng.8b03190

Guo, Y., Zhou, J., Wen, J., Sun, G., and Sun, Y. (2015). Structural Transformations of Triploid of Populus Tomentosa Carr. Lignin during Auto-Catalyzed Ethanol Organosolv Pretreatment. Ind. Crops Prod. 76, 522-529. doi:10.1016/ j.indcrop.2015.06.020

Guo, Z., Ling, Z., Wang, C., Zhang, X., and Xu, F. (2018). Integration of Facile Deep Eutectic Solvents Pretreatment for Enhanced Enzymatic Hydrolysis and Lignin Valorization from Industrial Xylose Residue. Bioresour. Technol. 265, 334-339. doi:10.1016/j.biortech.2018.06.027

Guo, Z., Zhang, Q., You, T., Zhang, X., Xu, F., and Wu, Y. (2019). Short-time Deep Eutectic Solvent Pretreatment for Enhanced Enzymatic Saccharification and Lignin Valorization. Green. Chem. 21, 3099-3108. doi:10.1039/C9GC00704K

Hallac, B. B., Pu, Y., and Ragauskas, A. J. (2010). Chemical Transformations of Buddleja Davidii Lignin during Ethanol Organosolv Pretreatment. Energy Fuels 24, 2723-2732. doi:10.1021/ef901556u

Hansen, M. A. T., Kristensen, J. B., Felby, C., and Jørgensen, H. (2011). Pretreatment and Enzymatic Hydrolysis of Wheat Straw (Triticum aestivum L.) - the Impact of Lignin Relocation and Plant Tissues on Enzymatic Accessibility. Bioresour. Technol. 102, 2804-2811. doi:10.1016/j.biortech.2010.10.030 
Hansen, B. B., Spittle, S., Chen, B., Poe, D., Zhang, Y., Klein, J. M., et al. (2021). Deep Eutectic Solvents: A Review of Fundamentals and Applications. Chem. Rev. 121, 1232-1285. doi:10.1021/acs.chemrev.0c00385

Hassanpour, M., Abbasabadi, M., Gebbie, L., Te'o, V. S. J., O'Hara, I. M., and Zhang, Z. (2020). Acid-Catalyzed Glycerol Pretreatment of Sugarcane Bagasse: Understanding the Properties of Lignin and its Effects on Enzymatic Hydrolysis. ACS Sustain. Chem. Eng. 8, 10380-10388. doi:10.1021/acssuschemeng.0c01832

He, J., Huang, C., Lai, C., Huang, C., Li, X., and Yong, Q. (2018). Elucidation of Structure-Inhibition Relationship of Monosaccharides Derived Pseudo-lignin in Enzymatic Hydrolysis. Ind. Crops Prod. 113, 368-375. doi:10.1016/ j.indcrop.2018.01.046

He, J., Huang, C., Lai, C., Jin, Y., Ragauskas, A., and Yong, Q. (2020a). Investigation of the Effect of Lignin/pseudo-Lignin on Enzymatic Hydrolysis by Quartz Crystal Microbalance. Ind. Crops Prod. 157, 112927-112934. doi:10.1016/ j.indcrop.2020.112927

He, J., Huang, C., Lai, C., Huang, C., Li, M., Pu, Y., et al. (2020b). The Effect of Lignin Degradation Products on the Generation of Pseudo-lignin during Dilute Acid Pretreatment. Ind. Crops Prod. 146, 112205-112212. doi:10.1016/ j.indcrop. 2020.112205

Ho, M. C., Wu, T. Y., Chee, S. W. Q., Ngang, C. Y., Chew, I. M. L., Teoh, W. H., et al. (2019). An Application of Low Concentration Alkaline Hydrogen Peroxide at Non-severe Pretreatment Conditions Together with Deep Eutectic Solvent to Improve Delignification of Oil palm Fronds. Cellulose 26, 8557-8573. doi:10.1007/s10570-019-02646-z

Hodgson, K. T., and Berg, J. C. (1988). Dynamic Wettability Properties of Single Wood Pulp Fibers and Their Relationship to Absorbency. Wood Fiber Sci. 20, 3-17. doi:10.1007/BF00031858

Hu, F., Jung, S., and Ragauskas, A. (2013). Impact of Pseudolignin Versus Dilute Acid-Pretreated Lignin on Enzymatic Hydrolysis of Cellulose. ACS Sustain. Chem. Eng. 1, 62-65. doi:10.1021/sc300032J

Hu, F., Jung, S., and Ragauskas, A. (2012). Pseudo-Lignin Formation and its Impact on Enzymatic Hydrolysis. Bioresour. Technol. 117, 7-12. doi:10.1016/ j.biortech.2012.04.037

Huang, X., Korányi, T. I., Boot, M. D., and Hensen, E. J. M. (2015). Ethanol as Capping Agent and Formaldehyde Scavenger for Efficient Depolymerization of Lignin to Aromatics. Green. Chem. 17 (11), 4941-4950. doi:10.1039/c5gc01120e

Huang, C., He, J., Min, D., Lai, C., and Yong, Q. (2016). Understanding the Nonproductive Enzyme Adsorption and Physicochemical Properties of Residual Lignins in Moso Bamboo Pretreated with Sulfuric Acid and Kraft Pulping. Appl. Biochem. Biotechnol. 180, 1508-1523. doi:10.1007/s12010-016-2183-8

Huang, Y., Sun, S., Huang, C., Yong, Q., Elder, T., and Tu, M. (2017). Stimulation and Inhibition of Enzymatic Hydrolysis by Organosolv Lignins as Determined by Zeta Potential and Hydrophobicity. Biotechnol. Biofuels 10, 162. doi:10.1186/ s13068-017-0853-6

Huang, Y., Lai, C., Sun, S., Yong, Q., Via, B. K., and Tu, M. (2020a). Organosolv Lignin Properties and Their Effects on Enzymatic Hydrolysis. BioRes 15, 8909-8924. doi:10.15376/biores.15.4.8909-8924

Huang, C., Fang, G., Zhou, Y., Du, X., Yu, L., Meng, X., et al. (2020b). Increasing the Carbohydrate Output of Bamboo Using a Combinatorial Pretreatment. ACS Sustain. Chem. Eng. 8, 7380-7393. doi:10.1021/acssuschemeng.0c01126

Huang, C., Zhan, Y., Cheng, J., Wang, J., Meng, X., Zhou, X., et al. (2021). Facilitating Enzymatic Hydrolysis with a Novel Guaiacol-Based Deep Eutectic Solvent Pretreatment. Bioresour. Technol. 326, 124696-124701. doi:10.1016/ j.biortech.2021.124696

Imai, T., Yokoyama, T., and Matsumoto, Y. (2011). Revisiting the Mechanism of $\beta-\mathrm{O}-4$ Bond Cleavage during Acidolysis of Lignin IV: Dependence of Acidolysis Reaction on the Type of Acid. J. Wood Sci. 57, 219-225. doi:10.1007/s10086-010-1166-6

Ji, H., and Lv, P. (2020). Mechanistic Insights into the Lignin Dissolution Behaviors of a Recyclable Acid Hydrotrope, Deep Eutectic Solvent (DES), and Ionic Liquid (IL). Green. Chem. 22, 1378-1387. doi:10.1039/C9GC02760B

Ji, Q., Yu, X., Yagoub, A. E. A., Chen, L., Mustapha, A. T., and Zhou, C. (2021). Enhancement of Lignin Removal and Enzymolysis of Sugarcane Bagasse by Ultrasound-Assisted Ethanol Synergized Deep Eutectic Solvent Pretreatment. Renew. Energ. 172, 304-316. doi:10.1016/j.renene.2021.03.050

Kangas, H., Liitiä, T., Rovio, S., Ohra-aho, T., Heikkinen, H., Tamminen, T., et al. (2015). Characterization of Dissolved Lignins from Acetic Acid Lignofibre (LGF) Organosolv Pulping and Discussion of its Delignification Mechanisms. Holzforschung 69, 247-256. doi:10.1515/hf-2014-0070
Karlsson, O., Lundquist, K., Meuller, S., Westlid, K., Lönnberg, H., Berg, J.-E., et al. (1988). On the Acidolytic Cleavage of Arylglycerol Beta-Aryl Ethers. Acta Chem. Scand. 42b (1), 48-51. doi:10.3891/acta.chem.scand.42b-0048

Kim, M. H., Lee, S. B., Ryu, D. D. Y., and Reese, E. T. (1982). Surface Deactivation of Cellulase and its Prevention. Enzyme Microb. Technol. 4 (2), 99-103. doi:10.1016/0141-0229(82)90090-4

Kim, Y., Ximenes, E., Mosier, N. S., and Ladisch, M. R. (2011). Soluble Inhibitors/ deactivators of Cellulase Enzymes from Lignocellulosic Biomass. Enzyme Microb. Technol. 48, 408-415. doi:10.1016/j.enzmictec.2011.01.007

Kim, K. H., Dutta, T., Sun, J., Simmons, B., and Singh, S. (2018). Biomass Pretreatment Using Deep Eutectic Solvents from Lignin Derived Phenols. Green. Chem. 20, 809-815. doi:10.1039/C7GC03029K

Kim, K. H., Eudes, A., Jeong, K., Yoo, C. G., Kim, C. S., and Ragauskas, A. (2019). Integration of Renewable Deep Eutectic Solvents with Engineered Biomass to Achieve a Closed-Loop Biorefinery. Proc. Natl. Acad. Sci. USA 116, 13816-13824. doi:10.1073/pnas.1904636116

Ko, J. K., Ximenes, E., Kim, Y., and Ladisch, M. R. (2015a). Adsorption of Enzyme onto Lignins of Liquid Hot Water Pretreated Hardwoods. Biotechnol. Bioeng. 112, 447-456. doi:10.1002/bit.25359

Ko, J. K., Kim, Y., Ximenes, E., and Ladisch, M. R. (2015b). Effect of Liquid Hot Water Pretreatment Severity on Properties of Hardwood Lignin and Enzymatic Hydrolysis of Cellulose. Biotechnol. Bioeng. 112, 252-262. doi:10.1002/bit.25349

Korányi, T. I., Fridrich, B., Pineda, A., and Barta, K. (2020). Development of 'Lignin-First' Approaches for the Valorization of Lignocellulosic Biomass. Molecules 25, 2815-2836. doi:10.3390/molecules25122815

Lai, C., Tu, M., Shi, Z., Zheng, K., Olmos, L. G., and Yu, S. (2014). Contrasting Effects of Hardwood and Softwood Organosolv Lignins on Enzymatic Hydrolysis of Lignocellulose. Bioresour. Technol. 163, 320-327. doi:10.1016/ j.biortech.2014.04.065

Lai, C., Tu, M., Yong, Q., and Yu, S. (2015). Disparate Roles of Solvent Extractable Lignin and Residual Bulk Lignin in Enzymatic Hydrolysis of Pretreated Sweetgum. RSC Adv. 5, 97966-97974. doi:10.1039/C5RA22308C

Lai, C., Yang, B., He, J., Huang, C., Li, X., Song, X., et al. (2018a). Enhanced Enzymatic Digestibility of Mixed wood Sawdust by Lignin Modification with Naphthol Derivatives during Dilute Acid Pretreatment. Bioresour. Technol. 269, 18-24. doi:10.1016/j.biortech.2018.08.086

Lai, C., Tu, M., Yong, Q., and Yu, S. (2018b). Synergistic Effects of pH and Organosolv Lignin Addition on the Enzymatic Hydrolysis of OrganosolvPretreated Loblolly pine. RSC Adv. 8, 13835-13841. doi:10.1039/C8RA00902C

Lai, C., Yang, B., Lin, Z., Jia, Y., Huang, C., Li, X., et al. (2019). New Strategy to Elucidate the Positive Effects of Extractable Lignin on Enzymatic Hydrolysis by Quartz crystal Microbalance with Dissipation. Biotechnol. Biofuels 12, 57-68. doi:10.1186/s13068-019-1402-2

Li, A.-L., Hou, X.-D., Lin, K.-P., Zhang, X., and Fu, M.-H. (2018). Rice Straw Pretreatment Using Deep Eutectic Solvents with Different Constituents Molar Ratios: Biomass Fractionation, Polysaccharides Enzymatic Digestion and Solvent Reuse. J. Biosci. Bioeng. 126, 346-354. doi:10.1016/j.jbiosc.2018.03.011

Li, X., and Zheng, Y. (2017). Lignin-enzyme Interaction: Mechanism, Mitigation Approach, Modeling, and Research Prospects. Biotechnol. Adv. 35, 466-489. doi:10.1016/j.biotechadv.2017.03.010

Li, C., Huang, C., Zhao, Y., Zheng, C., Su, H., Zhang, L., et al. (2021). Effect of Choline-Based Deep Eutectic Solvent Pretreatment on the Structure of Cellulose and Lignin in Bagasse. Processes 9, 384-397. doi:10.3390/pr9020384

Li, H., Pu, Y., Kumar, R., Ragauskas, A. J., and Wyman, C. E. (2014). Investigation of Lignin Deposition on Cellulose during Hydrothermal Pretreatment, its Effect on Cellulose Hydrolysis, and Underlying Mechanisms. Biotechnol. Bioeng. 111, 485-492. doi:10.1002/bit.25108

Li, M., Pu, Y., and Ragauskas, A. J. (2016a). Current Understanding of the Correlation of Lignin Structure with Biomass Recalcitrance. Front. Chem. 4, 45. doi:10.3389/fchem.2016.00045

Li, Y., Qi, B., Luo, J., and Wan, Y. (2016b). Effect of Alkali Lignins with Different Molecular Weights from Alkali Pretreated rice Straw Hydrolyzate on Enzymatic Hydrolysis. Bioresour. Technol. 200, 272-278. doi:10.1016/ j.biortech.2015.10.038

Li, W., Amos, K., Li, M., Pu, Y., Debolt, S., Ragauskas, A. J., et al. (2018). Fractionation and Characterization of Lignin Streams from Unique HighLignin Content Endocarp Feedstocks. Biotechnol. Biofuels 11, 304-317. doi:10.1186/s13068-018-1305-7 
Li, W.-X., Xiao, W.-Z., Yang, Y.-Q., Wang, Q., Chen, X., Xiao, L.-P., et al. (2021). Insights into Bamboo Delignification with Acidic Deep Eutectic Solvents Pretreatment for Enhanced Lignin Fractionation and Valorization. Ind. Crops Prod. 170, 113692. doi:10.1016/j.indcrop.2021.113692

Lin, W., Xing, S., Jin, Y., Lu, X., Huang, C., and Yong, Q. (2020). Insight into Understanding the Performance of Deep Eutectic Solvent Pretreatment on Improving Enzymatic Digestibility of Bamboo Residues. Bioresour. Technol. 306, 123163-123171. doi:10.1016/j.biortech.2020.123163

Liu, Z.-H., Olson, M. L., Shinde, S., Wang, X., Hao, N., Yoo, C. G., et al. (2017). Synergistic Maximization of the Carbohydrate Output and Lignin Processability by Combinatorial Pretreatment. Green. Chem. 19, 4939-4955. doi:10.1039/C7GC02057K

Liu, Z.-H., Xie, S., Lin, F., Jin, M., and Yuan, J. S. (2018). Combinatorial Pretreatment and Fermentation Optimization Enabled a Record Yield on Lignin Bioconversion. Biotechnol. Biofuels 11, 21-40. doi:10.1186/s13068-018-1021-3

Liu, X., Feng, S., Fang, Q., Jiang, Z., and Hu, C. (2020). Reductive Catalytic Fractionation of Lignin in Birch Sawdust to Monophenolic Compounds with High Selectivity. Mol. Catal. 495, 111164-111173. doi:10.1016/ j.mcat.2020.111164

Liu, Y., Deak, N., Wang, Z., Yu, H., Hameleers, L., Jurak, E., et al. (2021). Tunable and Functional Deep Eutectic Solvents for Lignocellulose Valorization. Nat. Commun. 12, 5424-5438. doi:10.1038/s41467-021-25117-1

Liu, X., Li, H., Xiao, L.-P., Sun, R.-C., and Song, G. (2019). Chemodivergent Hydrogenolysis of eucalyptus Lignin with Ni@ZIF-8 Catalyst. Green. Chem. 21, 1498-1504. doi:10.1039/C8GC03511C

Liu, Z.-H., Hao, N., Shinde, S., Olson, M. L., Bhagia, S., Dunlap, J. R., et al. (2019). Codesign of Combinatorial Organosolv Pretreatment (COP) and Lignin Nanoparticles (LNPs) in Biorefineries. ACS Sustain. Chem. Eng. 7, 2634-2647. doi:10.1021/acssuschemeng.8b05715

Lou, H., Zhu, J. Y., Lan, T. Q., Lai, H., and Qiu, X. (2013). pH-Induced Lignin Surface Modification to Reduce Nonspecific Cellulase Binding and Enhance Enzymatic Saccharification of Lignocelluloses. ChemSusChem 6, 919-927. doi:10.1002/cssc.201200859

Lu, X., Zheng, X., Li, X., and Zhao, J. (2016). Adsorption and Mechanism of Cellulase Enzymes onto Lignin Isolated from Corn stover Pretreated with Liquid Hot Water. Biotechnol. Biofuels 9, 118-129. doi:10.1186/s13068-016-0531-0

Lu, X., Wang, C., Li, X., Zhao, J., and Zhao, X. (2017). Studying Nonproductive Adsorption Ability and Binding Approach of Cellobiohydrolase to Lignin during Bioconversion of Lignocellulose. Energy Fuels 31, 14393-14400. doi:10.1021/acs.energyfuels.7b02427

Lundquist, K., Lundgren, R., Danielsen, J., Haaland, A., and Svensson, S. (1972). Acid Degradation of Lignin. Part VII. The Cleavage of Ether Bonds. Acta Chem. Scand. 26, 2005-2023. doi:10.3891/acta.chem.scand.26-2005

Luo, H., Klein, I. M., Jiang, Y., Zhu, H., Liu, B., Kenttämaa, H. I., et al. (2016). Total Utilization of Miscanthus Biomass, Lignin and Carbohydrates, Using Earth Abundant Nickel Catalyst. ACS Sustain. Chem. Eng. 4, 2316-2322. doi:10.1021/ acssuschemeng. $5 \mathrm{~b} 01776$

Luo, X., Gong, Z., Shi, J., Chen, L., Zhu, W., Zhou, Y., et al. (2020). Integrating Benzenesulfonic Acid Pretreatment and Bio-Based Lignin-Shielding Agent for Robust Enzymatic Conversion of Cellulose in Bamboo. Polymers 12, 191-205. doi:10.3390/polym12010191

Luterbacher, J. S., Rand, J. M., Alonso, D. M., Han, J., Youngquist, J. T., Maravelias, C. T., et al. (2014). Nonenzymatic Sugar Production from Biomass Using BiomassDerived $\gamma$-Valerolactone. Science 343, 277-280. doi:10.1126/science.1246748

Ma, C.-Y., Gao, X., Peng, X.-P., Gao, Y.-F., Liu, J., Wen, J.-L., et al. (2021). Microwaveassisted Deep Eutectic Solvents (DES) Pretreatment of Control and Transgenic Poplars for Boosting the Lignin Valorization and Cellulose Bioconversion. Ind. Crops Prod. 164, 113415-113423. doi:10.1016/j.indcrop.2021.113415

Mateo, W., Lei, H., Villota, E., Qian, M., Zhao, Y., Huo, E., et al. (2021). One-step Synthesis of Biomass-Based Sulfonated Carbon Catalyst by Direct Carbonization-Sulfonation for Organosolv Delignification. Bioresour. Technol. 319, 124194. doi:10.1016/j.biortech.2020.124194

Meng, X., Bhagia, S., Wang, Y., Zhou, Y., Pu, Y., Dunlap, J. R., et al. (2020). Effects of the Advanced Organosolv Pretreatment Strategies on Structural Properties of Woody Biomass. Ind. Crops Prod. 146, 112144-112155. doi:10.1016/j.indcrop.2020.112144

Meng, X., Pu, Y., Li, M., and Ragauskas, A. J. (2020b). A Biomass Pretreatment Using Cellulose-Derived Solvent Cyrene. Green. Chem. 22, 2862-2872. doi:10.1039/D0GC00661K
Min, D.-y., Xu, R.-s., Hou, Z., Lv, J.-q., Huang, C.-x., Jin, Y.-c., et al. (2015). Minimizing Inhibitors during Pretreatment while Maximizing Sugar Production in Enzymatic Hydrolysis through a Two-Stage Hydrothermal Pretreatment. Cellulose 22, 1253-1261. doi:10.1007/s10570-015-0552-z

Mostofian, B., Cai, C. M., Smith, M. D., Petridis, L., Cheng, X., Wyman, C. E., et al. (2016). Local Phase Separation of Co-solvents Enhances Pretreatment of Biomass for Bioenergy Applications. J. Am. Chem. Soc. 138, 10869-10878. doi:10.1021/jacs.6b03285

Mou, H., and Wu, S. (2017). Comparison of Hydrothermal, Hydrotropic and Organosolv Pretreatment for Improving the Enzymatic Digestibility of Bamboo. Cellulose 24, 85-94. doi:10.1007/s10570-016-1117-5

Moxley, G., Gaspar, A. R., Higgins, D., and Xu, H. (2012). Structural Changes of Corn stover Lignin during Acid Pretreatment. J. Ind. Microbiol. Biot. 39, 1289-1299. doi:10.1007/s10295-012-1131-z

Mukasekuru, M. R., Hu, J., Zhao, X., Sun, F. F., Pascal, K., Ren, H., et al. (2018). Enhanced High-Solids Fed-Batch Enzymatic Hydrolysis of Sugar Cane Bagasse with Accessory Enzymes and Additives at Low Cellulase Loading. ACS Sustain. Chem. Eng. 6, 12787-12796. doi:10.1021/acssuschemeng.8b01972

Pan, X. (2008). Role of Functional Groups in Lignin Inhibition of Enzymatic Hydrolysis of Cellulose to Glucose. J. Biobased Mat. Bioenergy 2, 25-32. doi:10.1166/jbmb.2008.005

Pareek, N., Gillgren, T., and Jönsson, L. J. (2013). Adsorption of Proteins Involved in Hydrolysis of Lignocellulose on Lignins and Hemicelluloses. Bioresour. Technol. 148, 70-77. doi:10.1016/j.biortech.2013.08.121

Parsell, T., Yohe, S., Degenstein, J., Jarrell, T., Klein, I., Gencer, E., et al. (2015). A Synergistic Biorefinery Based on Catalytic Conversion of Lignin Prior to Cellulose Starting from Lignocellulosic Biomass. Green. Chem. 17, 1492-1499. doi:10.1039/c4gc01911c

Patri, A. S., Mostofian, B., Pu, Y., Ciaffone, N., Soliman, M., Smith, M. D., et al. (2019). A Multifunctional Cosolvent Pair Reveals Molecular Principles of Biomass Deconstruction. J. Am. Chem. Soc. 141, 12545-12557. doi:10.1021/jacs.8b10242

Patri, A. S., Mohan, R., Pu, Y., Yoo, C. G., Ragauskas, A. J., Kumar, R., et al. (2021). THF Co-solvent Pretreatment Prevents Lignin Redeposition from Interfering with Enzymes Yielding Prolonged Cellulase Activity. Biotechnol. Biofuels 14, 63-75. doi:10.1186/s13068-021-01904-2

Pinto, A. S. S., Brondi, M. G., de Freitas, J. V., Furlan, F. F., Ribeiro, M. P. A., Giordano, R. C., et al. (2021). Mitigating the Negative Impact of Soluble and Insoluble Lignin in Biorefineries. Renew. Energ. 173, 1017-1026. doi:10.1016/ j.renene.2021.03.137

Pu, Y., Hu, F., Huang, F., Davison, B. H., and Ragauskas, A. J. (2013). Assessing the Molecular Structure Basis for Biomass Recalcitrance during Dilute Acid and Hydrothermal Pretreatments. Biotechnol. Biofuels 6, 15-27. doi:10.1186/17546834-6-15

Qin, C., Clarke, K., and Li, K. (2014). Interactive Forces between Lignin and Cellulase as Determined by Atomic Force Microscopy. Biotechnol. Biofuels 7 , 65-73. doi:10.1186/1754-6834-7-65

Qin, L., Li, W.-C., Liu, L., Zhu, J.-Q., Li, X., Li, B.-Z., et al. (2016). Inhibition of Lignin-Derived Phenolic Compounds to Cellulase. Biotechnol. Biofuels 9, 70-79. doi:10.1186/s13068-016-0485-2

Ragauskas, A. J., Beckham, G. T., Biddy, M. J., Chandra, R., Chen, F., Davis, M. F., et al. (2014). Lignin Valorization: Improving Lignin Processing in the Biorefinery. Science 344, 1246843. doi:10.1126/science.1246843

Rinaldi, R., Jastrzebski, R., Clough, M. T., Ralph, J., Kennema, M., Bruijnincx, P. C. A., et al. (2016). Paving the Way for Lignin Valorisation: Recent Advances in Bioengineering, Biorefining and Catalysis. Angew. Chem. Int. Ed. 55, 8164-8215. doi:10.1002/anie.201510351

Sadeghifar, H., Wells, T., Le, R. K., Sadeghifar, F., Yuan, J. S., and Jonas Ragauskas, A. (2017). Fractionation of Organosolv Lignin Using Acetone:Water and Properties of the Obtained Fractions. ACS Sustain. Chem. Eng. 5, 580-587. doi:10.1021/acssuschemeng.6b01955

Sai, Y. W., and Lee, K. M. (2019). Enhanced Cellulase Accessibility Using AcidBased Deep Eutectic Solvent in Pretreatment of Empty Fruit Bunches. Cellulose 26, 9517-9528. doi:10.1007/s10570-019-02770-w

Saini, J. K., Patel, A. K., Adsul, M., and Singhania, R. R. (2016). Cellulase Adsorption on Lignin: A Roadblock for Economic Hydrolysis of Biomass. Renew. Energ. 98, 29-42. doi:10.1016/j.renene.2016.03.089

Sammond, D. W., Yarbrough, J. M., Mansfield, E., Bomble, Y. J., Hobdey, S. E., Decker, S. R., et al. (2014). Predicting Enzyme Adsorption to Lignin Films by 
Calculating Enzyme Surface Hydrophobicity. J. Biol. Chem. 289, 20960-20969. doi:10.1074/jbc.M114.573642

Samuel, R., Pu, Y., Raman, B., and Ragauskas, A. J. (2010). Structural Characterization and Comparison of Switchgrass ball-milled Lignin before and after Dilute Acid Pretreatment. Appl. Biochem. Biotechnol. 162, 62-74. doi:10.1007/s12010-009-8749-y

Sannigrahi, P., Ragauskas, A. J., and Miller, S. J. (2010). Lignin Structural Modifications Resulting from Ethanol Organosolv Treatment of Loblolly Pine. Energy Fuels 24, 683-689. doi:10.1021/ef900845t

Sannigrahi, P., Kim, D. H., Jung, S., and Ragauskas, A. (2011). Pseudo-lignin and Pretreatment Chemistry. Energ. Environ. Sci. 4, 1306-1310. doi:10.1039/c0ee00378f

Schutyser, W., Van den Bosch, S., Renders, T., De Boe, T., Koelewijn, S.-F., Dewaele, A., et al. (2015). Influence of Bio-Based Solvents on the Catalytic Reductive Fractionation of Birch wood. Green. Chem. 17, 5035-5045. doi:10.1039/c5gc01442e

Schutyser, W., Renders, T., Van den Bosch, S., Koelewijn, S.-F., Beckham, G. T., and Sels, B. F. (2018). Chemicals from Lignin: an Interplay of Lignocellulose Fractionation, Depolymerisation, and Upgrading. Chem. Soc. Rev. 47, 852-908. doi:10.1039/c7cs00566k

Selig, M. J., Viamajala, S., Decker, S. R., Tucker, M. P., Himmel, M. E., and Vinzant, T. B. (2007). Deposition of Lignin Droplets Produced During Dilute Acid Pretreatment of Maize Stems Retards Enzymatic Hydrolysis of Cellulose. Biotechnol. Prog. 23, 1333-1339. doi:10.1021/bp0702018

Selig, M. J., Knoshaug, E. P., Adney, W. S., Himmel, M. E., and Decker, S. R. (2008). Synergistic Enhancement of Cellobiohydrolase Performance on Pretreated Corn stover by Addition of Xylanase and Esterase Activities. Bioresour. Technol. 99, 4997-5005. doi:10.1016/j.biortech.2007.09.064

Shi, J., Liu, J., Li, M., Huang, L., Chen, L., and Luo, X. (2018). Acid-Free EthanolWater Pretreatment with Low Ethanol Concentration for Robust Enzymatic Saccharification of Cellulose in Bamboo. Bioenerg. Res. 11, 665-676. doi:10.1007/s12155-018-9928-x

Shinde, S. D., Meng, X., Kumar, R., and Ragauskas, A. J. (2018). Recent Advances in Understanding the Pseudo-lignin Formation in a Lignocellulosic Biorefinery. Green. Chem. 20, 2192-2205. doi:10.1039/C8GC00353J

Shuai, L., Amiri, M. T., Questell-Santiago, Y. M., Héroguel, F., Li, Y., Kim, H., et al. (2016a). Formaldehyde Stabilization Facilitates Lignin Monomer Production during Biomass Depolymerization. Science 354, 329-333. doi:10.1126/science.aaf7810

Shuai, L., Questell-Santiago, Y. M., and Luterbacher, J. S. (2016b). A Mild Biomass Pretreatment Using $\gamma$-valerolactone for Concentrated Sugar Production. Green. Chem. 18, 937-943. doi:10.1039/c5gc02489g

Smith, M. D., Mostofian, B., Cheng, X., Petridis, L., Cai, C. M., Wyman, C. E., et al. (2016). Cosolvent Pretreatment in Cellulosic Biofuel Production: Effect of Tetrahydrofuran-Water on Lignin Structure and Dynamics. Green. Chem. 18, 1268-1277. doi:10.1039/c5gc01952d

Song, Y., Chandra, R. P., Zhang, X., Tan, T., and Saddler, J. N. (2019). Comparing a Deep Eutectic Solvent (DES) to a Hydrotrope for Their Ability to Enhance the Fractionation and Enzymatic Hydrolysis of Willow and Corn stover. Sustain. Energ. Fuels 3, 1329-1337. doi:10.1039/C8SE00617B

Song, Y., Chandra, R. P., Zhang, X., and Saddler, J. N. (2020). Non-productive Celluase Binding onto Deep Eutectic Solvent (DES) Extracted Lignin from Willow and Corn stover with Inhibitory Effects on Enzymatic Hydrolysis of Cellulose. Carbohydr. Polym. 250, 116956-116965. doi:10.1016/j.carbpol.2020.116956

Su, C., Hirth, K., Liu, Z., Cao, Y., and Zhu, J. Y. (2021). Acid Hydrotropic Fractionation of Switchgrass at Atmospheric Pressure Using Maleic Acid in Comparison with P-TsOH: Advantages of Lignin Esterification. Ind. Crops Prod. 159, 113017. doi:10.1016/j.indcrop.2020.113017

Sun, Q., Pu, Y., Meng, X., Wells, T., and Ragauskas, A. J. (2015). Structural Transformation of Isolated Poplar and Switchgrass Lignins during Dilute Acid Treatment. ACS Sustain. Chem. Eng. 3, 2203-2210. doi:10.1021/ acssuschemeng.5b00426

Sun, S., Huang, Y., Sun, R., and Tu, M. (2016). The strong Association of Condensed Phenolic Moieties in Isolated Lignins with Their Inhibition of Enzymatic Hydrolysis. Green. Chem. 18, 4276-4286. doi:10.1039/C6GC00685J

Tan, Y. T., Ngoh, G. C., and Chua, A. S. M. (2019). Effect of Functional Groups in Acid Constituent of Deep Eutectic Solvent for Extraction of Reactive Lignin. Bioresour. Technol. 281, 359-366. doi:10.1016/j.biortech.2019.02.010

Tian, S., Zhu, W., Gleisner, R., Pan, X. J., and Zhu, J. Y. (2011). Comparisons of SPORL and Dilute Acid Pretreatments for Sugar and Ethanol Productions from Aspen. Biotechnol. Prog. 27, 419-427. doi:10.1002/btpr.545
Tian, Y., Jiang, Y., and Ou, S. (2013). Interaction of Cellulase with Three Phenolic Acids. Food Chem. 138, 1022-1027. doi:10.1016/j.foodchem.2012.10.129

Tokunaga, Y., Nagata, T., Kondo, K., Katahira, M., and Watanabe, T. (2020). NMR Elucidation of Nonproductive Binding Sites of Lignin Models with Carbohydrate-Binding Module of Cellobiohydrolase I. Biotechnol. Biofuels 13, 164-173. doi:10.1186/s13068-020-01805-w

Wan, G., Zhang, Q., Li, M., Jia, Z., Guo, C., Luo, B., et al. (2019). How Pseudo-lignin Is Generated during Dilute Sulfuric Acid Pretreatment. J. Agric. Food Chem. 67, 10116-10125. doi:10.1021/acs.jafc.9b02851

Wang, Z., and Jönsson, L. J. (2018). Comparison of Catalytically Non-productive Adsorption of Fungal Proteins to Lignins and Pseudo-lignin Using Isobaric Mass Tagging. Bioresour. Technol. 268, 393-401. doi:10.1016/j.biortech.2018.07.149

Wang, G. S., Pan, X. J., Zhu, J. Y., Gleisner, R., and Rockwood, D. (2009). Sulfite Pretreatment to Overcome Recalcitrance of Lignocellulose (SPORL) for Robust Enzymatic Saccharification of Hardwoods. Biotechnol. Prog. 25, 1086-1093. doi:10.1002/btpr.206

Wang, Z., Lan, T., and Zhu, J. (2013a). Lignosulfonate and Elevated pH Can Enhance Enzymatic Saccharification of Lignocelluloses. Biotechnol. Biofuels 6, 9. doi:10.1186/1754-6834-6-9

Wang, Z., Zhu, J., Fu, Y., Qin, M., Shao, Z., Jiang, J., et al. (2013b). Lignosulfonatemediated Cellulase Adsorption: Enhanced Enzymatic Saccharification of Lignocellulose through Weakening Nonproductive Binding to Lignin. Biotechnol. Biofuels 6, 156. doi:10.1186/1754-6834-6-156

Wang, W., Zhu, Y., Du, J., Yang, Y., and Jin, Y. (2015a). Influence of Lignin Addition on the Enzymatic Digestibility of Pretreated Lignocellulosic Biomasses. Bioresour. Technol. 181, 7-12. doi:10.1016/j.biortech.2015.01.026

Wang, W., Zhuang, X., Yuan, Z., Yu, Q., and Qi, W. (2015b). Investigation of the Pellets Produced from Sugarcane Bagasse during Liquid Hot Water Pretreatment and Their Impact on the Enzymatic Hydrolysis. Bioresour. Technol. 190, 7-12. doi:10.1016/j.biortech.2015.04.059

Wang, S., Ouyang, X., Wang, W., Yuan, Q., and Yan, A. (2016). Comparison of Ultrasound-Assisted Fenton Reaction and Dilute Acid-Catalysed Steam Explosion Pretreatment of Corncobs: Cellulose Characteristics and Enzymatic Saccharification. RSC Adv. 6, 76848-76854. doi:10.1039/c6ra13125e

Wang, J., Hao, X., Wen, P., Zhang, T., and Zhang, J. (2020a). Adsorption and Desorption of Cellulase On/from Lignin Pretreated by Dilute Acid with Different Severities. Ind. Crops Prod. 148, 112309-112317. doi:10.1016/j.indcrop.2020.112309

Wang, S., Li, H., Xiao, L.-P., and Song, G. (2020b). Unraveling the Structural Transformation of Wood Lignin During Deep Eutectic Solvent Treatment. Front. Energ. Res. 8, 48-57. doi:10.3389/fenrg.2020.00048

Wang, Y., Meng, X., Jeong, K., Li, S., Leem, G., Kim, K. H., et al. (2020c). Investigation of a Lignin-Based Deep Eutectic Solvent Using $P$-Hydroxybenzoic Acid for Efficient Woody Biomass Conversion. ACS Sustain. Chem. Eng. 8, 12542-12553. doi:10.1021/acssuschemeng.0c03533

Wang, Y., Meng, X., Tian, Y., Kim, K. H., Jia, L., Pu, Y., et al. (2021a). Engineered Sorghum Bagasse Enables a Sustainable Biorefinery with P -Hydroxybenzoic Acid-Based Deep Eutectic Solvent. ChemSusChem. doi:10.1002/ cssc. 202101492

Wang, S., Sun, J., Chen, M., Hou, X., and Gao, Z. (2021b). Effect of Fenton Pretreatment on Enzymatic Hydrolysis of poplar. BioRes 16, 1980-1987. doi:10.15376/biores.16.1.1980-1987

Wen, J.-L., Xue, B.-L., Sun, S.-L., and Sun, R.-C. (2013). Quantitative Structural Characterization and thermal Properties of Birch Lignins after Auto-Catalyzed Organosolv Pretreatment and Enzymatic Hydrolysis. J. Chem. Technol. Biotechnol. 88, 1663-1671. doi:10.1002/jctb.4017

Wormeyer, K., Ingram, T., Saake, B., Brunner, G., and Smirnova, I. (2011). Comparison of Different Pretreatment Methods for Lignocellulosic Materials. Part II: Influence of Pretreatment on the Properties of Rye Straw Lignin. Bioresour. Technol. 102, 4157-4164. doi:10.1016/j.biortech.2010.11.063

Wu, L., Arakane, M., Ike, M., Wada, M., Takai, T., Gau, M., et al. (2011). Low Temperature Alkali Pretreatment for Improving Enzymatic Digestibility of Sweet Sorghum Bagasse for Ethanol Production. Bioresour. Technol. 102, 4793-4799. doi:10.1016/j.biortech.2011.01.023

Wu, K., Ying, W., Shi, Z., Yang, H., Zheng, Z., Zhang, J., et al. (2018). Fenton Reaction-Oxidized Bamboo Lignin Surface and Structural Modification to Reduce Nonproductive Cellulase Binding and Improve Enzyme Digestion of Cellulose. ACS Sustain. Chem. Eng. 6 (3), 3853-3861. doi:10.1021/ acssuschemeng.7b04191 
Xiao, L.-P., Bai, Y.-Y., Shi, Z.-J., Lu, Q., and Sun, R.-C. (2014). Influence of Alkaline Hydrothermal Pretreatment on Shrub wood Tamarix Ramosissima : Characteristics of Degraded Lignin. Biomass Bioenergy 68, 82-94. doi:10.1016/j.biombioe.2014.06.010

Ximenes, E., Kim, Y., Mosier, N., Dien, B., and Ladisch, M. (2010). Inhibition of Cellulases by Phenols. Enzyme Microb. Technol. 46, 170-176. doi:10.1016/ j.enzmictec.2009.11.001

Xu, C., Liu, F., Alam, M. A., Chen, H., Zhang, Y., Liang, C., et al. (2020). Comparative Study on the Properties of Lignin Isolated from Different Pretreated Sugarcane Bagasse and its Inhibitory Effects on Enzymatic Hydrolysis. Int. J. Biol. Macromol. 146, 132-140. doi:10.1016/j.ijbiomac.2019.12.270

Yan, Z., Li, J., Chang, S., Cui, T., Jiang, Y., Yu, M., et al. (2015). Lignin Relocation Contributed to the Alkaline Pretreatment Efficiency of Sweet Sorghum Bagasse. Fuel 158, 152-158. doi:10.1016/j.fuel.2015.05.029

Yang, Q., and Pan, X. (2016). Correlation between Lignin Physicochemical Properties and Inhibition to Enzymatic Hydrolysis of Cellulose. Biotechnol. Bioeng. 113, 1213-1224. doi:10.1002/bit.25903

Yang, B., and Wyman, C. E. (2006). BSA Treatment to Enhance Enzymatic Hydrolysis of Cellulose in Lignin Containing Substrates. Biotechnol. Bioeng. 94, 611-617. doi:10.1002/bit.20750

Yang, H., Xie, Y., Zheng, X., Pu, Y., Huang, F., Meng, X., et al. (2016). Comparative Study of Lignin Characteristics from Wheat Straw Obtained by Soda-AQ and Kraft Pretreatment and Effect on the Following Enzymatic Hydrolysis Process. Bioresour. Technol. 207, 361-369. doi:10.1016/j.biortech.2016.01.123

Yang, J., Tu, M., Xia, C., Keller, B., Huang, Y., and Sun, F. F. (2019). Effect of Fenton Pretreatment on $\mathrm{C} 1$ and $\mathrm{C} 6$ Oxidation of Cellulose and its Enzymatic Hydrolyzability. ACS Sustain. Chem. Eng. 7, 7071-7079. doi:10.1021/ acssuschemeng.8b06850

Yang, H., Zhang, Y., Yoo, C., Meng, X., Chen, X., Ragauskas, A., et al. (2020). Physico-chemical Properties of Lignin Fractions from Acid Pretreated Corn Stover and Their Effects on Enzymatic Hydrolysis of Microcrystalline Cellulose. BioRes 15, 4898-4911. doi:10.15376/biores.15.3.4898-4911

Yao, L., Zhao, J., Xie, Y., Qu, Y., and Yang, H. (2012). Effect of Lignin Structure and Surfactant on Cellulase Adsorption by Lignin. CIESC J. 63, 2612-2616. doi:10.3969/j.issn.0438-1157.2012.08.038

Yao, L., Yang, H., Yoo, C. G., Meng, X., Li, M., Pu, Y., et al. (2017). Adsorption of Cellobiohydrolases I onto Lignin Fractions from Dilute Acid Pretreated Broussonetia Papyrifera. Bioresour. Technol. 244, 957-962. doi:10.1016/ j.biortech.2017.08.024

Yao, L., Yoo, C. G., Meng, X., Li, M., Pu, Y., Ragauskas, A. J., et al. (2018a). A Structured Understanding of Cellobiohydrolase I Binding to poplar Lignin Fractions after Dilute Acid Pretreatment. Biotechnol. Biofuels 11, 96-105. doi:10.1186/s13068-018-1087-y

Yao, L., Chen, C., Yoo, C. G., Meng, X., Li, M., Pu, Y., et al. (2018b). Insights of Ethanol Organosolv Pretreatment on Lignin Properties of Broussonetia Papyrifera. ACS Sustain. Chem. Eng. 6, 14767-14773. doi:10.1021/ acssuschemeng.8b03290

Yao, L., Xiong, L., Yoo, C. G., Dong, C., Meng, X., Dai, J., et al. (2020). Correlations of the Physicochemical Properties of Organosolv Lignins from Broussonetia Papyrifera with Their Antioxidant Activities. Sustain. Energ. Fuels 4, 5114-5119. doi:10.1039/D0SE00940G

Yao, L., Yang, H., Yoo, C. G., Chen, C., Meng, X., Dai, J., et al. (2021). A Mechanistic Study of Cellulase Adsorption onto Lignin. Green. Chem. 23, 333-339. doi:10.1039/D0GC02463E

Yarbrough, J. M., Mittal, A., Mansfield, E., Taylor, L. E., II, Hobdey, S. E., Sammond, D. W., et al. (2015). New Perspective on Glycoside Hydrolase Binding to Lignin from Pretreated Corn stover. Biotechnol. Biofuels 8, 214-227. doi:10.1186/s13068-015-0397-6

Ying, W., Xu, G., Yang, H., Shi, Z., and Yang, J. (2019). The Sequential Fenton Oxidation and Sulfomethylation Pretreatment for Alleviating the Negative Effects of Lignin in Enzymatic Saccharification of Sugarcane Bagasse. Bioresour. Technol. 286, 121392-121398. doi:10.1016/j.biortech.2019.121392

Yoo, C. G., Meng, X., Pu, Y., and Ragauskas, A. J. (2020). The Critical Role of Lignin in Lignocellulosic Biomass Conversion and Recent Pretreatment Strategies: a Comprehensive Review. Bioresour. Technol. 301, 122784-122793. doi:10.1016/ j.biortech.2020.122784
Yu, Z., Gwak, K.-S., Treasure, T., Jameel, H., Chang, H.-m., and Park, S. (2014). Effect of Lignin Chemistry on the Enzymatic Hydrolysis of Woody Biomass. ChemSusChem 7, 1942-1950. doi:10.1002/cssc.201400042

Zeng, Y., Zhao, S., Wei, H., Tucker, M. P., Himmel, M. E., Mosier, N. S., et al. (2015). In Situ micro-spectroscopic Investigation of Lignin in poplar Cell walls Pretreated by Maleic Acid. Biotechnol. Biofuels 8, 126-135. doi:10.1186/s13068015-0312-1

Zhang, Z., Harrison, M. D., Rackemann, D. W., Doherty, W. O. S., and O'Hara, I. M. (2016). Organosolv Pretreatment of Plant Biomass for Enhanced Enzymatic Saccharification. Green. Chem. 18, 360-381. doi:10.1039/c5gc02034d

Zhang, K., Si, M., Liu, D., Zhuo, S., Liu, M., Liu, H., et al. (2018). A Bionic System with Fenton Reaction and Bacteria as a Model for Bioprocessing Lignocellulosic Biomass. Biotechnol. Biofuels 11, 31-44. doi:10.1186/s13068-018-1035-x

Zhang, K., Sun, Q., Wei, L., Sun, J., Li, K., Zhang, J., et al. (2021). Characterization of Lignin Streams during Ionic Liquid/hydrochloric Acid/formaldehyde Pretreatment of Corn Stalk. Bioresour. Technol. 331, 125064-125068. doi:10.1016/j.biortech.2021.125064

Zheng, Y., Pan, Z., Zhang, R., Wang, D., and Jenkins, B. (2008). Non-ionic Surfactants and Non-Catalytic Protein Treatment on Enzymatic Hydrolysis of Pretreated Creeping Wild Ryegrass. Appl. Biochem. Biotechnol. 146, 231-248. doi:10.1007/s12010-007-8035-9

Zhou, H., Lou, H., Yang, D., Zhu, J. Y., and Qiu, X. (2013). Lignosulfonate to Enhance Enzymatic Saccharification of Lignocelluloses: Role of Molecular Weight and Substrate Lignin. Ind. Eng. Chem. Res. 52, 8464-8470. doi:10.1021/ie401085k

Zhu, J. Y., Pan, X. J., Wang, G. S., and Gleisner, R. (2009). Sulfite Pretreatment (SPORL) for Robust Enzymatic Saccharification of spruce and Red pine. Bioresour. Technol. 100, 2411-2418. doi:10.1016/j.biortech.2008.10.057

Zhu, M.-Q., Wen, J.-L., Su, Y.-Q., Wei, Q., and Sun, R.-C. (2015). Effect of Structural Changes of Lignin during the Autohydrolysis and Organosolv Pretreatment on Eucommia Ulmoides Oliver for an Effective Enzymatic Hydrolysis. Bioresour. Technol. 185, 378-385. doi:10.1016/j.biortech.2015.02.061

Author Disclaimer: The United States Government retains and the publisher, by accepting the article for publication, acknowledges that the United States government retains a nonexclusive, paid-up, irrevocable, world-wide license to publish or reproduce the published form of this manuscript, or allow others to do so, for United States government purposes. The Department of Energy will provide public access to these results of federally sponsored research in accordance with the DOE Public Access Plan (http://energy.gov/downloads/doe-public-access-plan). The views and opinions of the authors expressed herein do not necessarily state or reflect those of the United States Government or any agency thereof. Neither the United States Government nor any agency thereof, nor any of their employees, makes any warranty, expressed or implied, or assumes any legal liability or responsibility for the accuracy, completeness, or usefulness of any information, apparatus, product, or process disclosed, or represents that its use would not infringe privately owned rights.

Conflict of Interest: The authors declare that the research was conducted in the absence of any commercial or financial relationships that could be construed as a potential conflict of interest.

Publisher's Note: All claims expressed in this article are solely those of the authors and do not necessarily represent those of their affiliated organizations, or those of the publisher, the editors and the reviewers. Any product that may be evaluated in this article, or claim that may be made by its manufacturer, is not guaranteed or endorsed by the publisher.

Copyright $\odot 2022$ Yao, Yang, Meng and Ragauskas. This is an open-access article distributed under the terms of the Creative Commons Attribution License (CC BY). The use, distribution or reproduction in other forums is permitted, provided the original author(s) and the copyright owner(s) are credited and that the original publication in this journal is cited, in accordance with accepted academic practice. No use, distribution or reproduction is permitted which does not comply with these terms. 